\title{
Halocarbon emissions and sources in the equatorial Atlantic Cold Tongue
}

\author{
H. Hepach ${ }^{1}$, B. Quack ${ }^{1}$, S. Raimund ${ }^{1}$, T. Fischer ${ }^{1}$, E. L. Atlas ${ }^{2}$, and A. Bracher ${ }^{3,4}$ \\ ${ }^{1}$ GEOMAR Helmholtz Centre for Ocean Research Kiel, Germany \\ ${ }^{2}$ Rosenstiel School of Marine and Atmospheric Science (RSMAS), University of Miami, Florida, USA \\ ${ }^{3}$ Helmholtz-University Young Investigators Group PHYTOOPTICS, Alfred-Wegener-Institute \\ (AWI) Helmholtz Center for Polar and Marine Research, Bremerhaven, Germany \\ ${ }^{4}$ Institute of Environmental Physics, University of Bremen, Germany \\ Correspondence to: H. Hepach (hhepach@geomar.de)
}

Received: 23 February 2015 - Published in Biogeosciences Discuss.: 14 April 2015

Accepted: 25 September 2015 - Published: 9 November 2015

\begin{abstract}
Halocarbons from oceanic sources contribute to halogens in the troposphere, and can be transported into the stratosphere where they take part in ozone depletion. This paper presents distribution and sources in the equatorial Atlantic from June and July 2011 of the four compounds bromoform $\left(\mathrm{CHBr}_{3}\right)$, dibromomethane $\left(\mathrm{CH}_{2} \mathrm{Br}_{2}\right)$, methyl iodide $\left(\mathrm{CH}_{3} \mathrm{I}\right)$ and diiodomethane $\left(\mathrm{CH}_{2} \mathrm{I}_{2}\right)$. Enhanced biological production during the Atlantic Cold Tongue (ACT) season, indicated by phytoplankton pigment concentrations, led to elevated concentrations of $\mathrm{CHBr}_{3}$ of up to 44.7 and up to 9.2 $\mathrm{pmol} \mathrm{L}^{-1}$ for $\mathrm{CH}_{2} \mathrm{Br}_{2}$ in surface water, which is comparable to other tropical upwelling systems. While both compounds correlated very well with each other in the surface water, $\mathrm{CH}_{2} \mathrm{Br}_{2}$ was often more elevated in greater depth than $\mathrm{CHBr}_{3}$, which showed maxima in the vicinity of the deep chlorophyll maximum. The deeper maximum of $\mathrm{CH}_{2} \mathrm{Br}_{2}$ indicates an additional source in comparison to $\mathrm{CHBr}_{3}$ or a slower degradation of $\mathrm{CH}_{2} \mathrm{Br}_{2}$. Concentrations of $\mathrm{CH}_{3} \mathrm{I}$ of up to $12.8 \mathrm{pmol} \mathrm{L}^{-1}$ in the surface water were measured. In contrary to expectations of a predominantly photochemical source in the tropical ocean, its distribution was mostly in agreement with biological parameters, indicating a biological source. $\mathrm{CH}_{2} \mathrm{I}_{2}$ was very low in the near surface water with maximum concentrations of only $3.7 \mathrm{pmol} \mathrm{L}^{-1}$. $\mathrm{CH}_{2} \mathrm{I}_{2}$ showed distinct maxima in deeper waters similar to $\mathrm{CH}_{2} \mathrm{Br}_{2}$. For the first time, diapycnal fluxes of the four halocarbons from the upper thermocline into and out of the mixed layer were determined. These fluxes were low in comparison to the halocarbon sea-to-air fluxes. This indicates that
\end{abstract}

despite the observed maximum concentrations at depth, production in the surface mixed layer is the main oceanic source for all four compounds and one of the main driving factors of their emissions into the atmosphere in the ACTregion. The calculated production rates of the compounds in the mixed layer are $34 \pm 65 \mathrm{pmol} \mathrm{m}^{-3} \mathrm{~h}^{-1}$ for $\mathrm{CHBr}_{3}$, $10 \pm 12 \mathrm{pmol} \mathrm{m}^{-3} \mathrm{~h}^{-1}$ for $\mathrm{CH}_{2} \mathrm{Br}_{2}, 21 \pm 24 \mathrm{pmol} \mathrm{m}^{-3} \mathrm{~h}^{-1}$ for $\mathrm{CH}_{3} \mathrm{I}$ and $384 \pm 318 \mathrm{pmol} \mathrm{m}^{-3} \mathrm{~h}^{-1}$ for $\mathrm{CH}_{2} \mathrm{I}_{2}$ determined from 13 depth profiles.

\section{Introduction}

Oceanic upwelling regions where cold nutrient rich water is brought to the surface are connected to enhanced primary production and elevated halocarbon production, especially of bromoform $\left(\mathrm{CHBr}_{3}\right)$ and dibromomethane $\left(\mathrm{CH}_{2} \mathrm{Br}_{2}\right.$; Quack et al., 2007a; Carpenter et al., 2009; Raimund et al., 2011; Hepach et al., 2014). Photochemical formation (Moore and Zafiriou, 1994; Richter and Wallace, 2004) with a possible involvement of organic precursors is an important source for methyl iodide $\left(\mathrm{CH}_{3} \mathrm{I}\right)$. An abiotic formation pathway for halocarbons involving ozone has been found for diiodomethane $\left(\mathrm{CH}_{2} \mathrm{I}_{2}\right)$ in the laboratory (Martino et al., 2009). But, its production is generally suggested to be biotic, occurring likely through different species of phytoplankton than are involved in the production of $\mathrm{CHBr}_{3}$ and $\mathrm{CH}_{2} \mathrm{Br}_{2}$ (Moore et al., 1996; Orlikowska and Schulz-Bull, 2009). Additionally, bacterial involvement in the formation of halocarbons 
e.g. $\mathrm{CH}_{3} \mathrm{I}$ and $\mathrm{CH}_{2} \mathrm{I}_{2}$ has been observed in the field and the laboratory (Manley and Dastoor, 1988; Amachi et al., 2001; Fuse et al., 2003; Amachi, 2008). Large uncertainties regarding the production of halocarbons in the ocean remain. Depth profiles of the different compounds provide insight into the processes participating in their cycling. Elevated concentrations of $\mathrm{CHBr}_{3}$ and $\mathrm{CH}_{2} \mathrm{Br}_{2}$ at the bottom of the mixed layer and below, often close to the chlorophyll $a(\mathrm{Chl} a)$ subsurface maximum, are a common feature in the water column (Yamamoto et al., 2001; Quack et al., 2004; Liu et al., 2013a), and are attributed to enhanced production by phytoplankton. While occasionally $\mathrm{CH}_{3} \mathrm{I}$ maxima close to the $\mathrm{Chl} a$ maximum were observed as well (Moore and Groszko, 1999; Wang et al., 2009), Happell and Wallace (1996) ascribed surface maxima in several oceanic regions including the equatorial Atlantic to a predominantly photochemical source. Rapid photolysis and biogenic sources in the deep Chl $a$ maximum are suggested to determine the depth distribution of $\mathrm{CH}_{2} \mathrm{I}_{2}$ concentrations (Moore and Tokarczyk, 1993; Yamamoto et al., 2001; Carpenter et al., 2007; Kurihara et al., 2010). The complex interactions between the sources (biogenic and nonbiogenic production), sinks (hydrolysis, photolysis, chlorine substitution and air-sea gas exchange), advection, and turbulent mixing in and out of the mixed layer (diapycnal fluxes), which determine the water concentrations of these compounds, are still sparsely investigated.

Once they are produced in the ocean, halocarbons can be transported from the oceanic mixed layer into the troposphere via air-sea gas transfer. $\mathrm{CHBr}_{3}$ and $\mathrm{CH}_{2} \mathrm{Br}_{2}$ are the largest contributors to atmospheric organic bromine from the ocean (Penkett et al., 1985; Schauffler et al., 1998; Hossaini et al., 2012). Marine $\mathrm{CH}_{3} \mathrm{I}$ is the most abundant organoiodine in the troposphere, while the very short-lived $\mathrm{CH}_{2} \mathrm{I}_{2}$ and $\mathrm{CH}_{2} \mathrm{ClI}$ contribute potentially as much organic iodine (Saiz-Lopez et al., 2012). Significant amounts of halocarbons and their degradation products can be carried into the stratosphere (Solomon et al., 1994; Hossaini et al., 2010; Aschmann et al., 2011), especially in the tropical regions where surface air can be transported very rapidly into the tropical tropopause layer by tropical deep convection (Tegtmeier et al., 2012; Tegtmeier et al., 2013). The short-lived brominated and iodinated halocarbons produced in the equatorial region may hence play an important role for stratospheric halogens.

This paper characterizes the distribution of $\mathrm{CHBr}_{3}$, $\mathrm{CH}_{2} \mathrm{Br}_{2}, \mathrm{CH}_{3} \mathrm{I}$, and $\mathrm{CH}_{2} \mathrm{I}_{2}$ in the surface water and the water column of the equatorial Atlantic Cold Tongue (ACT) for the first time. The ACT is a known feature in the equatorial region, which is characterized by intensive cooling of SSTs. This cooling is also associated with phytoplankton blooms (Grodsky et al., 2008) as a potential source for halocarbons. $\mathrm{CHBr}_{3}, \mathrm{CH}_{2} \mathrm{Br}_{2}, \mathrm{CH}_{3} \mathrm{I}$ and $\mathrm{CH}_{2} \mathrm{I}_{2}$ with important implications for atmospheric chemistry are poorly characterized in the ACT region. We therefore aim to provide more insight into the biological and physical processes contributing to the mixed layer budget of halocarbons in the equatorial Atlantic.
Sea-to-air fluxes and, for the first time, diapycnal fluxes from the upper thermocline are calculated as sources and sinks for the mixed layer. Phytoplankton groups (obtained from pigment concentrations) are evaluated as potential sources of these four compounds. Additionally, surface water halocarbons are correlated to meta data such as temperature, salinity and global radiation to understand their distribution further. Finally, we estimate production rates for the mixed layer of the ACT region.

\section{Methods}

Cruise MSM18/3 onboard the RV Maria S. Merian took place from June 21 to July 21 2011. One goal of the campaign was the characterization of the Atlantic equatorial upwelling with regard to halocarbon emissions and their sources. RV Maria S. Merian started in Mindelo (Sao Vicente, Cape Verde) at $16.9^{\circ} \mathrm{N}$ and $25.0^{\circ} \mathrm{W}$, and finished in Libreville (Gabon) at $0.4^{\circ} \mathrm{N}$ and $13.4^{\circ} \mathrm{E}$ with several transects across the equator. The ship entered the ACT several times. Measurements of halocarbons and phytoplankton pigments were conducted in surface water along the cruise track, and at 13 stations (Fig. 1). Samples for dissolved halocarbons from sea surface water were taken from a continuously working pump in the ships moon pool at a depth of about $6.5 \mathrm{~m}$ every $3 \mathrm{~h}$. Deep water samples were taken from up to eight different depths per station between 10 and $700 \mathrm{~m}$ from $12 \mathrm{~L}$ Niskin bottles attached to a 24-bottle-rosette with a CTD (conductivity temperature depth). Halocarbon stations 1-4 were located at the first meridional transect across the ACT at $15^{\circ} \mathrm{W}$, stations $5-7$ at the second transect at $10^{\circ} \mathrm{W}, 8-10$ were located at the third section at around $5^{\circ} \mathrm{W}$, and the last three stations $11-13$ were taken during the last section at $0^{\circ} \mathrm{E}$ (Fig. 1). Water temperature and salinity were recorded with a thermosalinograph. Air pressure and wind speed were derived from sensors in $30 \mathrm{~m}$ height, averaged in $10 \mathrm{~min}$ intervals, and wind speed was corrected to $10 \mathrm{~m}$. Global radiation was measured onboard in $19.5 \mathrm{~m}$ height with sensors (SMS-1 combined system from MesSen Nord, Germany) measuring downward incoming global radiation (GS, shortwave) and infrared radiation (IR, long wave).

\subsection{Sampling and analysis of halocarbons in seawater}

A purge and trap system attached to a gas chromatograph with mass spectrometric detection (GC-MS) in single ion mode was used to analyse $50 \mathrm{~mL}$ water samples for dissolved halocarbons. Volumetrically prepared standards in methanol were used for quantification. Precision lay within $3 \%$ for $\mathrm{CHBr}_{3}, 6 \%$ for $\mathrm{CH}_{2} \mathrm{Br}_{2}, 15 \%$ for $\mathrm{CH}_{3} \mathrm{I}$ and $20 \%$ for $\mathrm{CH}_{2} \mathrm{I}_{2}$ determined from duplicates. For a detailed description see Hepach et al. (2014). 


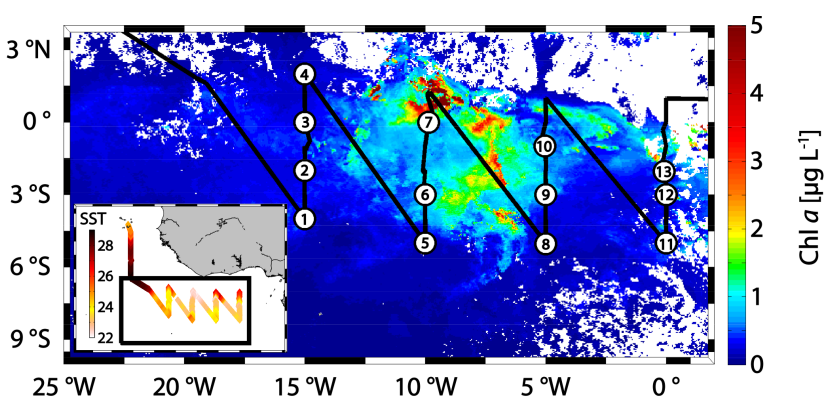

Figure 1. Cruise track with SST in ${ }^{\circ} \mathrm{C}$ (small box) and the section (large box) where halocarbons were sampled in both the sea surface and during CTD stations (numbered circles), plotted on monthly average Chl $a$ for July 2011 derived from mapped level 3 MODIS Aqua Data.

\subsection{Phytoplankton pigment analysis and continuous measurement of chlorophyll $a$}

Water samples were filtered onto GF/F filters, shock-frozen in liquid nitrogen and stored at $-80^{\circ} \mathrm{C}$. Pigments listed in Table 1 of Taylor et al. (2011) were analysed using a HPLC technique according to Barlow et al. (1997) as described in Taylor et al. (2011). Surface pigment data were already used in a study by Bracher et al. (2015). All pigment data are already published and available from PANGAEA (http://doi. pangaea.de/10.1594/PANGAEA.848586). For interpretation of the pigment data, CHEMTAX ${ }^{\circledR}$ (Mackey et al., 1996) was used, and initiated with the pigment ratio matrix proposed by Veldhuis and Kraay (2004) for the subtropical Atlantic Ocean. The following phytoplankton groups were evaluated: diatoms, Synechococcus-type, Prochlorococcus HL (highlight adapted) and Prochlorococcus $L L$ (low-light adapted), dinoflagellates, haptophytes, pelagophytes, cryptophytes and prasinophytes.

Ten minute-averaged continuous surface maximum fluorescence measured by a microFlu-chl fluorometer from TriOS located in the ships moon pool was used to derive continuous total $\mathrm{Chl} a$ ( $T \mathrm{Chl} a$ ) concentrations along the underway transect. This is based on the assumption that active fluorescence $\mathrm{F}$ is correlated to the amount of available $T$ Chl $a$ (Kolber and Falkowski, 1993). The method to convert fluorescence to $T \mathrm{Chl} a$ is described in detail in Taylor et al. (2011). Mean conversion factors specific for each zone were determined for collocated F and HPLC- $T$ Chl $a$ (the sum of monovinyl $\mathrm{Chl} a$, divinyl $\mathrm{Chl} a$ and Chlorophyllide $a$; the latter is mainly formed as artefact of the former two during the extraction process and therefore included in the calculation) measurements. A linear regression of $r=0.83$ ( $p<0.01, n=89)$ was observed between surface HPLC-derived $T \mathrm{Chl} a$ and F-derived $T \mathrm{Chl} a$, which indicates the robustness of the conversion of $\mathrm{F}$ to $T \mathrm{Chl} a$. The high depth resolved chlorophyll profiles were derived from fluorescence values obtained from a Dr. Haardt fluorometer mounted to the CTD and calibrated with collocated HPLCderived $T$ Chl $a$ concentrations at six depths of each profile according to Fujiki et al. (2011).

\subsection{Correlation analysis of halocarbons}

Different parameters were correlated to surface water halocarbons. Physical influences were investigated with $10 \mathrm{~min}$ averages of sea surface temperature (SST), sea surface salinity (SSS), global radiation and wind speed, and a relationship with location was explored using latitude. Biological parameters used for correlations were $T \mathrm{Chl} a$, and the abundance of all phytoplankton groups. Since most of the data sets were not normally distributed and common transformations into normal distributions were not possible, the Spearman's rank correlation coefficient $r_{\mathrm{s}}$ was applied. All correlations with $p<0.05$ were regarded as significant.

Correlation analysis of the entire depth profile data set using the Spearman's rank coefficient did not allow for drawing specific conclusions due to the complexity of the data set. Hence, the mixed influences on water column halocarbon concentrations were examined with principal component analysis (PCA) using MATLAB ${ }^{\circledR}$. PCA analyses the collective variance of a data set including several variables. The PCA has the advantage to simplify a complex data set and find similarities. Concentrations of all four halocarbons, all phytoplankton groups, the $T \mathrm{Chl} a$, density, temperature, and salinity were included.

\subsection{Mixed layer depth}

Mixed layer depths $z_{\mathrm{ML}}$ were determined using the method introduced by Kara et al. (2000). It proved to be closest to the visually determined $z_{\mathrm{ML}}$ from the temperature, salinity and density profiles. The mixed layer of each CTD profile was calculated as the depth where the temperature from the reference depth in the upper well-mixed temperature region was reduced by a threshold value of $0.8^{\circ} \mathrm{C}$.

\subsection{Calculation of sea-to-air fluxes of halocarbons}

The air-sea gas exchange parameterization of Nightingale et al. (2000) was applied to calculate sea-to-air fluxes $F_{\text {as }}$ of halocarbons (Eq. 1). Schmidt number corrections as reported by Quack and Wallace (2003) were applied to determine the compound-specific transfer coefficient $k_{\mathrm{w}}$. The air-sea concentration gradient was computed from sea surface water measurements and mean atmospheric mixing ratios $c_{\text {atm }}$ of $2.50 \mathrm{ppt}$ for $\mathrm{CHBr}_{3}, 1.20 \mathrm{ppt}$ for $\mathrm{CH}_{2} \mathrm{Br}_{2}$, and $0.50 \mathrm{ppt}$ for $\mathrm{CH}_{3} \mathrm{I}$ determined from 10 atmospheric data points during MSM18/3, and atmospheric mixing ratios of $0.01 \mathrm{ppt}$ for $\mathrm{CH}_{2} \mathrm{I}_{2}$ as reported by Jones et al. (2010) for the tropical Atlantic. Henry's law constants $H$ of Moore and co-workers (Moore et al., 1995a, b) were used to obtain the equilibrium 
Table 1. Mean (minimum - maximum) values of physical parameters (sea surface temperature (SST), sea surface salinity (SSS), and wind speed), surface biomass proxies ( $T$ Chl $a$-H: $T$ Chl $a$ from HPLC measurements, $T$ Chl $a$-F: $T$ Chl $a$ determined from the continuously measuring fluorescence sensor), and sea surface concentrations, as well as sea-to-air fluxes of the four halocarbons $\mathrm{CHBr}_{3}, \mathrm{CH}_{2} \mathrm{Br}_{2}, \mathrm{CH}_{3} \mathrm{I}$, and $\mathrm{CH}_{2} \mathrm{I}_{2}$ during the cruise MSM18/3.

\begin{tabular}{|c|c|c|c|c|c|c|c|c|c|c|c|c|c|}
\hline \multirow[t]{3}{*}{ Parameter } & \multirow[t]{3}{*}{ SST } & \multirow[t]{3}{*}{ SSS } & \multirow{3}{*}{ Wind speed } & \multicolumn{2}{|c|}{ Biomass proxies } & \multicolumn{8}{|c|}{ Halocarbons } \\
\hline & & & & \multirow[b]{2}{*}{$T \mathrm{Chl} a-\mathrm{H}$} & \multirow[b]{2}{*}{$T$ Chl $a-\mathrm{F}$} & \multicolumn{2}{|c|}{$\mathrm{CHBr}_{3}$} & \multicolumn{2}{|c|}{$\mathrm{CH}_{2} \mathrm{Br}_{2}$} & \multicolumn{2}{|c|}{$\mathrm{CH}_{3} \mathrm{I}$} & \multicolumn{2}{|c|}{$\mathrm{CH}_{2} \mathrm{I}_{2}$} \\
\hline & & & & & & Concentrations & $\begin{array}{r}\text { Sea-to-air } \\
\text { fluxes }\end{array}$ & Concentrations & $\begin{array}{r}\text { Sea-to-air } \\
\text { fluxes }\end{array}$ & Concentrations & $\begin{array}{r}\text { Sea-to-air } \\
\text { fluxes }\end{array}$ & Concentrations & $\begin{array}{r}\text { Sea-to-air } \\
\text { fluxes }\end{array}$ \\
\hline Unit & {$\left[{ }^{\circ} \mathrm{C}\right]$} & & {$\left[\mathrm{m} \mathrm{s}^{-1}\right]$} & {$[\mu \mathrm{g} \mathrm{L}$} & & {$\left[\mathrm{pmolL}^{-1}\right]$} & {$\left[\mathrm{pmol} \mathrm{m}{ }^{-2} \mathrm{~h}^{-1}\right]$} & {$\left[\mathrm{pmol} \mathrm{L}^{-1}\right]$} & {$\left[\mathrm{pmol} \mathrm{m} \mathrm{m}^{-2} \mathrm{~h}^{-1}\right]$} & {$\left[\mathrm{pmol} \mathrm{L}^{-1}\right]$} & {$\left[\mathrm{pmol} \mathrm{m}{ }^{-2} \mathrm{~h}^{-1}\right]$} & {$\left[\mathrm{pmol} \mathrm{L}^{-1}\right]$} & {$\left[\mathrm{pmol} \mathrm{m}^{-2} \mathrm{~h}^{-1}\right]$} \\
\hline Mean & 24.4 & 35.7 & 6.1 & 0.51 & 0.44 & 12.9 & 644 & 3.7 & 187 & 5.5 & 425 & 1.1 & 82 \\
\hline Min & 22.1 & 34.5 & 0.3 & 0.10 & 0.06 & 1.8 & -146 & 0.9 & -3 & 1.5 & 34 & 0.3 & 3 \\
\hline Max & 29.0 & 36.3 & 11.1 & 0.99 & 1.20 & 44.7 & 4285 & 9.2 & 762 & 12.8 & 1300 & 3.7 & 382 \\
\hline
\end{tabular}

concentrations $c_{\mathrm{atm}} / H$.

$F_{\mathrm{as}}=k_{\mathrm{w}} \cdot\left(c_{\mathrm{w}}-\frac{c_{\mathrm{atm}}}{H}\right)$

\subsection{Calculation of diapycnal fluxes of halocarbons}

To estimate the halocarbon transport perpendicular to the stratification, Eq. (2) was used with $F_{\text {dia }}$ as the diapycnal flux in mol m $\mathrm{m}^{-2} \mathrm{~s}^{-1}, \rho$ as the seawater density in $\mathrm{kg} \mathrm{m}^{-3}, \Delta c$ being the diapycnal gradient of the concentration in $\mathrm{mol} \mathrm{kg}^{-1}$, and $K_{\text {dia }}$ as the diapycnal diffusion coefficient in $\mathrm{m}^{2} \mathrm{~s}^{-1}$.

$F_{\text {dia }}=\rho \cdot K_{\text {dia }} \cdot \Delta c$.

In the equatorial near surface water, molecular and double diffusion are negligible compared to turbulent mixing. $K_{\text {dia }}$ from turbulent mixing can be estimated from measurements of the velocity microstructure (turbulent motions on length scales of centimetres to metres). During MSM18/3, velocity microstructure profiling was performed immediately before or after taking halocarbon profiles, so that local and pointwise in time estimates of the diapycnal flux resulted from the combination of the two profiles via equation 2 . The microstructure profiler (MSS) was a loosely tethered MSS90 equipped with airfoil shear probes, manufactured by Sea \& Sun Technology. In order to calculate $K_{\text {dia }}$ from velocity fluctuations measured by the MSS, first the average spectrum of vertical shear for a depth interval of typically 10 to $50 \mathrm{~m}$ was calculated and integrated to get an estimate of the average dissipation rate of turbulent kinetic energy (epsilon in $\mathrm{W} \mathrm{kg}^{-1}$ ). Equation (3), first proposed by Osborn (1980) allows to deduce $K_{\text {dia }}$, with $\gamma$ a function of the mixing efficiency and $N$ the buoyancy frequency for the chosen depth interval.

$K_{\mathrm{dia}}=\gamma \cdot \frac{\varepsilon}{N^{2}}$

$\gamma$ was chosen to be 0.2 following Hummels et al. (2013) for the tropical Atlantic. A more detailed description of the method to derive $K_{\text {dia }}$ and diapycnal fluxes below the mixed layer can be found in Schafstall et al. (2010), Hummels et al. (2013), and Schlundt et al. (2014).

\section{Physical and biological characteristics of the investigation area}

\subsection{Oceanographic description}

The equatorial Atlantic is described by a complex current system. The surface is characterized by the westward South Equatorial Current (SEC), which spreads between $3^{\circ} \mathrm{N}$ and $15^{\circ} \mathrm{S}$ and reaches as deep as $100 \mathrm{~m}$, but has shallow mixed layers close to the equator (Tomczak and Godfrey, 2005). The Equatorial Undercurrent (EUC) can be found below the SEC (Molinari, 1982), and is a narrow band between $2^{\circ} \mathrm{N}$ and $2^{\circ} \mathrm{S}$ flowing towards the east while reducing speed. It carries mostly water with characteristics of deeper tropical surface water (TSW) and of shallower central water. TSW around and north of the equator is characterized by high temperatures and comparably low salinities due to enhanced precipitation (Tsuchiya et al., 1992). While the core of the EUC in the west is at $100 \mathrm{~m}$, its position in the east follows the seasonal vertical migration of the thermocline (Stramma and Schott, 1999). In agreement with this, the mixed layer depth was shallow and ranged only between surface and $49 \mathrm{~m}$ with a mean of $28 \mathrm{~m}$ during MSM18/3. The mixed layer was also exposed to diurnal variability. During daytime, it was shallower due to warmer air temperatures and more stratification. At night, when the air temperature and SSTs cool, water mixes further down. The shallowest mixed layers were found between $0^{\circ} \mathrm{N}$ and $3^{\circ} \mathrm{S}$ in agreement with the location of the EUC. The Atlantic Cold Tongue (ACT) is a known feature in the equatorial region where SSTs between 20 and $5^{\circ} \mathrm{W}$ can drop by $5-7^{\circ} \mathrm{C}$ during May to September (Weingartner and Weisberg, 1991). Many uncertainties remain with respect to the exact mechanisms that lead to the development of the ACT. Jouanno et al. (2011) suggested that the strong increase of the westward SEC associated with the ITCZ (Philander and Pacanowski, 1986), and the maximum shear above the core of the underlying EUC lead to the low SSTs, confirmed later by microstructure measurements (Hummels et al., 2013; Schlundt et al., 2014). Although the shear is maximal at $0^{\circ} \mathrm{E}$, maximum cooling appears at $10^{\circ} \mathrm{W}$ due to the stronger stratification in the eastern basin of the equatorial Atlantic. SSTs during MSM18/3 of mean (range) $24.4(22.1-29.0)^{\circ} \mathrm{C}$ and 
Table 2. Spearman's rank correlation coefficients $r_{\mathrm{s}}$ of halocarbons with different physical parameters and phytoplankton species measured in surface water. Numbers printed in bold are regarded as significant with $p<0.05$.

\begin{tabular}{|c|c|c|c|c|c|c|c|c|c|c|c|c|c|c|}
\hline & $\mathrm{CHBr}_{3}$ & $\mathrm{CH}_{2} \mathrm{Br}_{2}$ & $\mathrm{CH}_{3} \mathrm{I}$ & $\mathrm{CH}_{2} \mathrm{I}_{2}$ & SST & Salinity & $\begin{array}{r}\text { Global } \\
\text { radiation }\end{array}$ & Latitude & $\begin{array}{l}\text { Wind } \\
\text { speed }\end{array}$ & $\begin{array}{r}\text { Chlorophyll } a \\
+ \text { Div a }\end{array}$ & Chlorophytes & Chrysophytes & Dinoflagellates & Haptophytes \\
\hline Prochlorococcus (HL) & -0.70 & -0.57 & -0.21 & 0.27 & 0.44 & -0.39 & -0.20 & 0.49 & 0.26 & -0.01 & 0.34 & -0.28 & -0.14 & -0.33 \\
\hline Haptophytes & 0.34 & 0.37 & 0.39 & -0.25 & -0.58 & 0.34 & 0.16 & -0.21 & -0.34 & 0.57 & -0.18 & 0.37 & 0.53 & \\
\hline Dinoflagellates & 0.22 & 0.22 & 0.29 & -0.02 & -0.50 & 0.10 & -0.14 & -0.33 & -0.37 & 0.72 & 0.09 & 0.40 & & \\
\hline Chrysophytes & 0.43 & 0.41 & 0.26 & 0.13 & -0.45 & 0.48 & -0.28 & -0.15 & -0.15 & 0.71 & 0.22 & & & \\
\hline Chlorophytes & -0.29 & -0.26 & -0.15 & 0.32 & 0.13 & -0.15 & -0.26 & 0.25 & -0.05 & 0.11 & & & & \\
\hline$T$ Chl $a$ & 0.23 & 0.27 & 0.36 & 0.04 & -0.58 & 0.35 & -0.22 & -0.13 & -0.27 & & & & & \\
\hline Wind speed & -0.18 & -0.16 & -0.22 & 0.20 & 0.56 & -0.06 & 0.12 & 0.04 & & & & & & \\
\hline Latitude & -0.38 & -0.18 & 0.03 & 0.12 & 0.10 & -0.20 & -0.08 & & & & & & & \\
\hline Global radiation & 0.05 & 0.04 & -0.09 & -0.25 & 0.19 & -0.09 & & & & & & & & \\
\hline SSS & 0.48 & 0.41 & -0.09 & -0.04 & -0.42 & & & & & & & & & \\
\hline SST & -0.46 & -0.46 & -0.42 & 0.33 & & & & & & & & & & \\
\hline $\mathrm{CH}_{2} \mathrm{I}_{2}$ & 0.07 & 0.09 & -0.04 & & & & & & & & & & & \\
\hline $\mathrm{CH}_{3} \mathrm{I}$ & 0.50 & 0.62 & & & & & & & & & & & & \\
\hline $\mathrm{CH}_{2} \mathrm{Br}_{2}$ & 0.90 & & & & & & & & & & & & & \\
\hline
\end{tabular}

SSSs of 35.7 (34.5-36.3) were measured in the investigated region (Table 1, Fig. 2). Generally, high SSTs and low SSSs of less than 35.5 in the TSW were observed north of the equator. Lower SSTs and higher SSSs were measured in the south except for the $10^{\circ} \mathrm{W}$ section where these low SSTs and high SSSs were also found north of the equator. Maximum SSTs around the equator of $28.5^{\circ} \mathrm{C}$ were found at $3^{\circ} \mathrm{N}$ and $20^{\circ} \mathrm{W}$, while the lowest SSTs of $22.1^{\circ} \mathrm{C}$ were located at $1^{\circ} \mathrm{N}$ and $10^{\circ} \mathrm{W}$ (Figs. 1, 2, Table 1).

\subsection{Biological description}

The cooling of SSTs in the ACT region is usually accompanied by a phytoplankton bloom. Grodsky et al. (2008) found a seasonal peak of $T \mathrm{Chl} a$ of $0.60 \mu \mathrm{g} \mathrm{L}^{-1}$ in boreal summer. In comparison, surface $T$ Chl $a$ during MSM18/3 reached values as high as $1.20 \mu \mathrm{g} \mathrm{L}^{-1}$ around $0.8^{\circ} \mathrm{N}$ and $0^{\circ} \mathrm{E}$ (Fig. 2c). Very high $T$ Chl $a$ concentrations above $1.00 \mu \mathrm{g} \mathrm{L}^{-1}$ were also measured from the continuous fluorescence sensor around $10^{\circ} \mathrm{W}$, coincidentally with the most intense cooling. The three hourly HPLC measurements of up to $0.99 \mu \mathrm{g} \mathrm{L}^{-1}$ generally also agree with the high $T$ Chl $a$ maximum values measured with the fluorescence sensor (Fig. 2, Table 1). Additionally, nitrate and phosphate were significantly anticorrelated with SST (not shown), hence the upwelled water of the EUC was connected to enhanced biological production.

The most abundant phytoplankton group in the ACT were chrysophytes in both surface water and depth profiles during MSM18/3 (Fig. 2a). Chrysophytes, golden algae with flagellar hairs, are thought to be mostly common in freshwater (Round, 1986). Nevertheless, they have been previously shown to be also the most abundant phytoplankton group in several regions of the Atlantic ocean, including the lower latitudes around the equator (Kirkham et al., 2011). This group correlated significantly with SST $\left(r_{\mathrm{s}}=-0.45\right)$ and SSS $\left(r_{\mathrm{s}}=0.48\right.$; Table 2$)$, it hence seems to be associated with the upwelling water of the EUC. In the surface water, chlorophytes and Prochlorococcus HL correlated positively with SST $\left(r_{\mathrm{s}}=0.13\right.$, not significant, and $r_{\mathrm{s}}=0.44$, significant) and negatively with SSS $\left(r_{\mathrm{S}}=-0.15\right.$, not significant, and $r_{\mathrm{s}}=-0.39$, significant). They were associated with warmer and less salty water masses than chrysophytes, dinoflagellates and haptophytes. Thus, they were found predominantly north of the equator. Prochlorococcus HL dominate among the species occurring from the surface down to $50 \mathrm{~m}$. Prochlorococcus LL, only observed in deeper layers (not shown here), were the most abundant group from about $75 \mathrm{~m}$ downwards in the water column. These results are in agreement with Johnson et al. (2006), where it was shown that Prochlorococcus dominate in oligotrophic tropical waters, especially where nutrient concentrations are low at high temperatures (between $15^{\circ} \mathrm{S}$ and $15^{\circ} \mathrm{N}$ of the Atlantic Ocean).

\section{Results}

\subsection{Surface water}

\subsection{1 $\mathrm{CHBr}_{3}$ and $\mathrm{CH}_{2} \mathrm{Br}_{2}$}

Large regional variations were observed for the bromocarbons, especially for $\mathrm{CHBr}_{3}$ in surface water of the tropical Atlantic with a mean of $12.9(1.8-44.7) \mathrm{pmol} \mathrm{L}^{-1}$, and of 3.7 (0.9-9.2) pmol L ${ }^{-1}$ for $\mathrm{CH}_{2} \mathrm{Br}_{2}$ (Fig. 2, Table 1). Concentrations from the underway measurements and from the shallowest profile depths $(<10 \mathrm{~m})$ were included in the evaluation of the surface water concentrations. The observed values are in agreement with data from the tropical oligotrophic Atlantic north of $16^{\circ} \mathrm{N}$ and the Mauritanian upwelling ranging between 1.0 and 43.6 for $\mathrm{CHBr}_{3}$ and $0.6-9.4 \mathrm{pmol} \mathrm{L}^{-1}$ for $\mathrm{CH}_{2} \mathrm{Br}_{2}$ with the largest values close to the coast and the upwelling (Quack et al., 2007a; Carpenter et al., 2009; Hepach et al., 2014). Quack et al. (2004) observed lower $\mathrm{CHBr}_{3}$ of $2.3 \mathrm{pmol} \mathrm{L}^{-1}$ and $\mathrm{CH}_{2} \mathrm{Br}_{2}$ of $0.2 \mathrm{pmol} \mathrm{L}^{-1}$ at $10^{\circ} \mathrm{N}$ through the tropical Atlantic in boreal fall and values of 12.8 and $5.3 \mathrm{pmol} \mathrm{L}^{-1}$ for $\mathrm{CHBr}_{3}$ and $\mathrm{CH}_{2} \mathrm{Br}_{2}$ at the equator in agreement with our study. Values of up to $10 \mathrm{pmol} \mathrm{L}^{-1}\left(\mathrm{CHBr}_{3}\right)$ and $3 \mathrm{pmol} \mathrm{L}^{-1}\left(\mathrm{CH}_{2} \mathrm{Br}_{2}\right)$ near the equator were reported by 


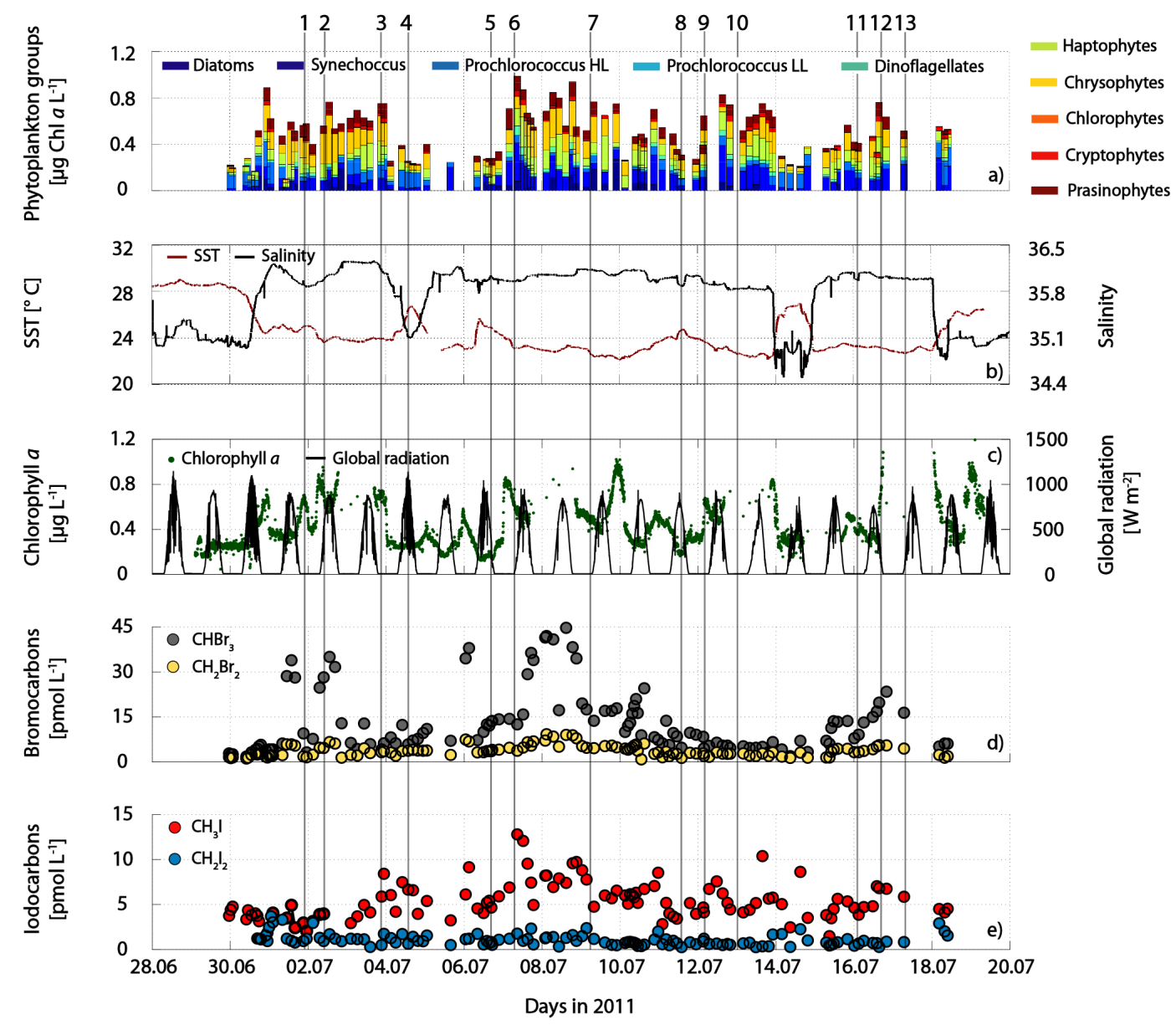

Figure 2. (a) Species composition (HL - high light, LL - low light), (b) SST and salinity during the cruise, (c) $T$ Chl $a$ from underway fluorescence sensor measurements and global radiation, (e) $\mathrm{CHBr}_{3}$ and $\mathrm{CH}_{2} \mathrm{Br}_{2}$ in surface sea water, and (e) $\mathrm{CH}_{3} \mathrm{I}$ and $\mathrm{CH}_{2} \mathrm{I}_{2}$ surface sea water concentrations. The top numbers mark the CTD stations.

Liu et al. (2013b). The latter study covers the region during October and November, indicating that the equatorial Atlantic seems to be a larger source for bromocarbons during the intense cooling in the summer months. Both compounds show the same pattern in surface water throughout the MSM18/3 cruise with hot spots slightly south of the equator.

The very good correlation between $\mathrm{CHBr}_{3}$ and $\mathrm{CH}_{2} \mathrm{Br}_{2}$ is in agreement with studies from several regions, mostly attributed to related sources for both compounds from macroand microalgae (Nightingale et al., 1995; Moore et al., 1996; Schall et al., 1997; Laturnus, 2001; Quack et al., 2007b; Karlsson et al., 2008). Significant correlations to SST, SSS and $T \mathrm{Chl} a$ were found for $\mathrm{CHBr}_{3}$ and $\mathrm{CH}_{2} \mathrm{Br}_{2}$, while very low insignificant correlations were observed with the $10 \mathrm{~min}$ averaged global radiation values (Table 2). The strongest correlations were found to Prochlorococcus $\mathrm{HL}$ with $r_{\mathrm{s}}=-0.70$ for $\mathrm{CHBr}_{3}$ and -0.57 for $\mathrm{CH}_{2} \mathrm{Br}_{2}$, and to chrysophytes with $r_{\mathrm{s}}=0.43$, and $r_{\mathrm{s}}=0.41$, respectively.

\subsection{2 $\mathrm{CH}_{3} \mathrm{I}$ and $\mathrm{CH}_{2} \mathrm{I}_{2}$}

The second highest mean sea surface water concentration was observed for $\mathrm{CH}_{3} \mathrm{I}$ of $5.5(1.5-12.8)$ pmol L $^{-1}$ (Fig. 2, Table 1), which is in the range of earlier studies. These studies were widely spread in the region from $20^{\circ} \mathrm{S}$ to $25^{\circ} \mathrm{N}$ between the coasts of South America and Africa with values between 0 and $36.5 \mathrm{pmol} \mathrm{L}^{-1}$ (Happell and Wallace, 1996; Schall et al., 1997; Richter and Wallace, 2004; Jones et al., 2010; Hepach et al., 2014). 7.1 to $16.4 \mathrm{pmol} \mathrm{L}^{-1}$ were detected in the vicinity of our investigated region (Richter and Wallace, 2004). $\mathrm{CH}_{2} \mathrm{I}_{2}$ was characterized by the lowest sea surface water concentrations of $1.1(0.3-3.7) \mathrm{pmol} \mathrm{L}^{-1}$ during MSM18/3. Literature reports of $\mathrm{CH}_{2} \mathrm{I}_{2}$ in the tropical Atlantic are very sparse: Schall et al. (1997) report on average three times higher values of $3.4(2.1-6.8) \mathrm{pmol} \mathrm{L}^{-1}$ in the tropical Atlantic, while Jones et al. (2010) measured a five times higher mean of $5.8(0.9$ and 17.1$) \mathrm{pmol} \mathrm{L}^{-1}$ (reported in Ziska et al., 2013) in the northern tropical Atlantic. 
Table 3. Concentrations of $\mathrm{CHBr}_{3}, \mathrm{CH}_{2} \mathrm{Br}_{2}$ and $T \mathrm{Chl} a$ (from HPLC measurements) averaged over different depths at every CTD station (1-13), as well as the mixed layer depth. If a range is not given, only one measurement point exists. Bold numbers indicate the depth of maximum concentrations at this station.

\begin{tabular}{|c|c|c|c|c|c|c|c|c|c|c|}
\hline & \multirow{3}{*}{$\begin{array}{l}z_{\mathrm{ML}} \\
{[\mathrm{m}]}\end{array}$} & \multicolumn{3}{|c|}{$0-30 \mathrm{~m}$} & \multicolumn{3}{|c|}{$31-60 \mathrm{~m}$} & \multicolumn{3}{|c|}{$61-100 \mathrm{~m}$} \\
\hline & & \multicolumn{2}{|c|}{$\begin{array}{l}\text { Concentrations } \\
{\left[\mathrm{pmol} \mathrm{L}^{-1}\right]}\end{array}$} & \multirow[t]{2}{*}{$\begin{array}{l}T \mathrm{Chl} a \\
{\left[\mu \mathrm{L} \mathrm{L}^{-} 1\right]}\end{array}$} & \multicolumn{2}{|c|}{$\begin{array}{l}\text { Concentrations } \\
{\left[\mathrm{pmol} \mathrm{L}^{-1}\right]}\end{array}$} & \multirow[t]{2}{*}{$\begin{array}{l}T \text { Chl } a \\
{\left[\mu \mathrm{L} \mathrm{L}^{-1}\right]}\end{array}$} & \multicolumn{2}{|c|}{$\begin{array}{l}\text { Concentrations } \\
{\left[\mathrm{pmol} \mathrm{L}^{1}\right]}\end{array}$} & \multirow[t]{2}{*}{$\begin{array}{l}T \text { Chl } a \\
{\left[\mu \mathrm{L} \mathrm{L}^{-1}\right]}\end{array}$} \\
\hline & & $\mathrm{CHBr}_{3}$ & $\mathrm{CH}_{2} \mathrm{Br}_{2}$ & & $\mathrm{CHBr}_{3}$ & $\mathrm{CH}_{2} \mathrm{Br}_{2}$ & & $\mathrm{CHBr}_{3}$ & $\mathrm{CH}_{2} \mathrm{Br}_{2}$ & \\
\hline 1 & 34 & $\begin{array}{l}5.4 \\
(3.2-6.5)\end{array}$ & $\begin{array}{l}1.7 \\
(1.3-2.1)\end{array}$ & $\begin{array}{l}0.60 \\
(0.52-0.69)\end{array}$ & $\begin{array}{l}5.8 \\
(3.7-7.9)\end{array}$ & $\begin{array}{l}3.0 \\
(1.8-4.2)\end{array}$ & $\begin{array}{l}0.59 \\
(0.53-0.65)\end{array}$ & 2.1 & 1.1 & - \\
\hline 2 & 16 & $\begin{array}{l}30.2 \\
(25.4-35.0)\end{array}$ & $\begin{array}{l}6.5 \\
(6.4-6.6)\end{array}$ & $\begin{array}{l}0.92 \\
(0.76-1.07)\end{array}$ & $\begin{array}{l}9.0 \\
(7.6-10.3)\end{array}$ & $\begin{array}{l}5.2 \\
(5.1-5.4)\end{array}$ & $\begin{array}{l}0.86 \\
(0.74-0.97)\end{array}$ & $\begin{array}{l}2.4 \\
(1.2-4.6)\end{array}$ & $\begin{array}{l}1.8 \\
(0.8-3.6)\end{array}$ & $\begin{array}{l}0.20 \\
(0.10-0.30)\end{array}$ \\
\hline 3 & 37 & $\begin{array}{l}6.8 \\
(6.2-7.4)\end{array}$ & $\begin{array}{l}3.9 \\
(3.6-4.2)\end{array}$ & $\begin{array}{l}0.80 \\
(0.75-0.86)\end{array}$ & $\begin{array}{l}3.0 \\
(2.6-3.2)\end{array}$ & $\begin{array}{l}2.4 \\
(2.4-2.5)\end{array}$ & $\begin{array}{l}0.65 \\
(0.51-0.80)\end{array}$ & $\begin{array}{l}2.3 \\
(2.2-2.5)\end{array}$ & $\begin{array}{l}2.3 \\
(2.3-2.3)\end{array}$ & 0.18 \\
\hline 4 & 14 & $\begin{array}{l}12.5 \\
(5.8-19.2)\end{array}$ & $\begin{array}{l}7.2 \\
(3.8-10.6)\end{array}$ & $\begin{array}{l}0.56 \\
(0.26-0.86)\end{array}$ & $\begin{array}{l}5.9 \\
(4.8-6.9)\end{array}$ & $\begin{array}{l}3.1 \\
(3.0-3.2)\end{array}$ & $\begin{array}{l}0.80 \\
(0.79-0.81)\end{array}$ & $\begin{array}{l}2.6 \\
(2.0-3.2)\end{array}$ & $\begin{array}{l}2.5 \\
(1.8-3.2)\end{array}$ & $\begin{array}{l}0.19 \\
(0.13-0.26)\end{array}$ \\
\hline 5 & 49 & $\begin{array}{l}14.0 \\
(13.6-14.4)\end{array}$ & $\begin{array}{l}4.2 \\
(4.0-4.3)\end{array}$ & $\begin{array}{l}0.34 \\
(0.28-0.39)\end{array}$ & 11.7 & 4.8 & 0.58 & $\begin{array}{l}7.6 \\
(6.6-8.5)\end{array}$ & $\begin{array}{l}7.4 \\
(6.1-8.6)\end{array}$ & $\begin{array}{l}0.39 \\
(0.24-0.53)\end{array}$ \\
\hline 6 & 12 & $\begin{array}{l}13.4 \\
(12.5-14.3)\end{array}$ & $\begin{array}{l}5.0 \\
(3.8-6.3)\end{array}$ & 0.99 & $\begin{array}{l}5.4 \\
(5.1-5.7)\end{array}$ & $\begin{array}{l}4.8 \\
(4.7-4.8)\end{array}$ & $\begin{array}{l}0.30 \\
(0.17-0.43)\end{array}$ & $\begin{array}{l}4.9 \\
(4.7-5.1)\end{array}$ & $\begin{array}{l}4.6 \\
(4.6-4.7)\end{array}$ & $\begin{array}{l}0.10 \\
(0.04-0.17)\end{array}$ \\
\hline 7 & - & $\begin{array}{l}11.2 \\
(8.8-13.7)\end{array}$ & $\begin{array}{l}4.6 \\
(3.5-4.6)\end{array}$ & $\begin{array}{l}0.71 \\
(0.65-0.76)\end{array}$ & $\begin{array}{l}3.7 \\
(2.5-4.9)\end{array}$ & $\begin{array}{l}3.4 \\
(2.5-4.2)\end{array}$ & $\begin{array}{l}0.46 \\
(0.44-0.48)\end{array}$ & $\begin{array}{l}3.1 \\
(2.9-3.4)\end{array}$ & $\begin{array}{l}3.0 \\
(2.9-3.1)\end{array}$ & $\begin{array}{l}0.11 \\
(0.06-0.17)\end{array}$ \\
\hline 8 & 45 & $\begin{array}{l}5.0 \\
(4.7-5.3)\end{array}$ & $\begin{array}{l}1.0 \\
(0.6-1.4)\end{array}$ & $\begin{array}{l}0.34 \\
(0.31-0.38)\end{array}$ & $\begin{array}{l}7.0 \\
(5.7-8.3)\end{array}$ & $\begin{array}{l}2.5 \\
(1.9-3.2)\end{array}$ & $\begin{array}{l}0.51 \\
(0.47-0.58)\end{array}$ & 1.1 & 1.5 & 0.51 \\
\hline 9 & 21 & $\begin{array}{l}3.6 \\
(2.7-4.5)\end{array}$ & $\begin{array}{l}1.8 \\
(1.6-2.0)\end{array}$ & $\begin{array}{l}0.75 \\
(0.64-0.85)\end{array}$ & $\begin{array}{l}8.9 \\
(7.4-10.3)\end{array}$ & $\begin{array}{l}4.2 \\
(3.9-4.6)\end{array}$ & $\begin{array}{l}0.77 \\
(0.68-0.85)\end{array}$ & $\begin{array}{l}5.4 \\
(4.5-6.3)\end{array}$ & $\begin{array}{l}3.2 \\
(2.6-3.7)\end{array}$ & $\begin{array}{l}0.24 \\
(0.17-0.32)\end{array}$ \\
\hline 10 & 10 & $\begin{array}{l}5.2 \\
(4.9-5.5)\end{array}$ & $\begin{array}{l}2.6 \\
(2.3-2.8)\end{array}$ & $\begin{array}{l}0.50 \\
(0.41-0.59)\end{array}$ & $\begin{array}{l}8.9 \\
(8.3-9.5)\end{array}$ & $\begin{array}{l}3.8 \\
(3.7-4.0)\end{array}$ & $\begin{array}{l}0.62 \\
(0.51-0.73)\end{array}$ & $\begin{array}{l}3.5 \\
(3.1-3.9)\end{array}$ & $\begin{array}{l}2.5 \\
(2.4-2.6)\end{array}$ & $\begin{array}{l}0.47 \\
(0.32-0.62)\end{array}$ \\
\hline 11 & 24 & $\begin{array}{l}6.0 \\
(4.1-7.9)\end{array}$ & $\begin{array}{l}2.5 \\
(1.8-3.3)\end{array}$ & $\begin{array}{l}0.46 \\
(0.42-0.49)\end{array}$ & 13.1 & 4.3 & 0.82 & $\begin{array}{l}4.0 \\
(2.5-6.8)\end{array}$ & $\begin{array}{l}4.0 \\
(2.8-6.0)\end{array}$ & $\begin{array}{l}0.23 \\
(0.04-0.44)\end{array}$ \\
\hline 12 & 35 & $\begin{array}{l}18.1 \\
(16.4-19.8)\end{array}$ & $\begin{array}{l}5.8 \\
(5.6-6.1)\end{array}$ & $\begin{array}{l}0.77 \\
(0.76-0.79)\end{array}$ & $\begin{array}{l}11.6 \\
(9.1-14.1)\end{array}$ & $\begin{array}{l}6.3 \\
(5.4-7.1)\end{array}$ & $\begin{array}{l}0.70 \\
(0.68-0.72)\end{array}$ & $\begin{array}{l}5.3 \\
(4.7-6.0)\end{array}$ & $\begin{array}{l}5.5 \\
(5.3-5.8)\end{array}$ & 0.25 \\
\hline 13 & 41 & $\begin{array}{l}11.6 \\
(6.9-16.4)\end{array}$ & $\begin{array}{l}3.5 \\
(2.5-4.4)\end{array}$ & $\begin{array}{l}0.55 \\
(0.51-0.58)\end{array}$ & $\begin{array}{l}8.9 \\
(8.3-9.5)\end{array}$ & $\begin{array}{l}4.6 \\
(3.0-5.6)\end{array}$ & $\begin{array}{l}0.16 \\
(0-0.48)\end{array}$ & $\begin{array}{l}5.9 \\
(3.3-7.6)\end{array}$ & $\begin{array}{l}5.2 \\
(4.1-5.7)\end{array}$ & $\begin{array}{l}0.12 \\
(0-0.30)\end{array}$ \\
\hline
\end{tabular}

Similar to $\mathrm{CHBr}_{3}$ and $\mathrm{CH}_{2} \mathrm{Br}_{2}$ sea surface $\mathrm{CH}_{3} \mathrm{I}$ was significantly anticorrelated with SST $\left(r_{\mathrm{S}}=-0.42\right)$ and not correlated with global radiation (Table 2). In contrast to the bromocarbons, correlations were neither found to SSS, nor to latitude. Additionally, sea surface $\mathrm{CH}_{3} \mathrm{I}$ correlated to biomass indicators ( $\left.T \mathrm{Chl} a: r_{\mathrm{s}}=0.36\right)$. The regional distribution of $\mathrm{CH}_{3} \mathrm{I}$ often followed qualitatively that of haptophytes $\left(r_{\mathrm{s}}=0.39\right)$ with the most elevated concentrations south of the equator. Positive correlations were also found to dinoflagellates $\left(r_{\mathrm{s}}=0.29\right)$ and chrysophytes $\left(r_{\mathrm{s}}=0.26\right)$. A weak, but significant anticorrelation was observed to wind speed $\left(r_{\mathrm{s}}=\right.$ -0.22 ). In contrast to the other three halocarbons, $\mathrm{CH}_{2} \mathrm{I}_{2}$ was positively correlated with SST $\left(r_{\mathrm{S}}=0.33\right)$, and elevated concentrations were observed mostly north of the equator. A weak negative correlation of $\mathrm{CH}_{2} \mathrm{I}_{2}$ was found with global radiation $\left(r_{\mathrm{s}}=-0.25\right)$, indicating higher sea surface $\mathrm{CH}_{2} \mathrm{I}_{2}$ during the night time and lower concentrations during the day. $\mathrm{CH}_{2} \mathrm{I}_{2}$ correlated both with chlorophytes $\left(r_{\mathrm{S}}=0.32\right)$ and Prochlorococcus $\mathrm{HL}\left(r_{\mathrm{s}}=0.27\right)$.

\subsection{Water column}

\subsection{1 $\mathrm{CHBr}_{3}$ and $\mathrm{CH}_{2} \mathrm{Br}_{2}$}

$\mathrm{CHBr}_{3}$ and $\mathrm{CH}_{2} \mathrm{Br}_{2}$ showed maxima at the surface, in the mixed layer and below it (Fig. 3, Table 3). The highest deep maximum concentrations of both $\mathrm{CHBr}_{3}$ (up to $19.2 \mathrm{pmol} \mathrm{L}^{-1}$ ) and $\mathrm{CH}_{2} \mathrm{Br}_{2}$ (up to $10.6 \mathrm{pmol} \mathrm{L}^{-1}$ ) were observed in profile 4. At stations where $\mathrm{CHBr}_{3}$ was most elevated at the surface (profiles 2, 7, 12,13), much higher overall $\mathrm{CHBr}_{3}$ concentrations of up to $35.0 \mathrm{pmol} \mathrm{L}^{-1}$ were measured. $\mathrm{CH}_{2} \mathrm{Br}_{2}$ only reached maximum values of up to $6.6 \mathrm{pmol} \mathrm{L}^{-1}$ in the surface (profiles 2,7).

In contrast to surface water, $\mathrm{CHBr}_{3}$ and $\mathrm{CH}_{2} \mathrm{Br}_{2}$ were distributed differently in the water column with $\mathrm{CH}_{2} \mathrm{Br}_{2}$ being elevated $10 \mathrm{~m}$ below $\mathrm{CHBr}_{3}$ in several profiles (Fig. 3e). This can also be seen in the T-S diagrams of these compounds (Fig. 4a, b): while the most elevated $\mathrm{CHBr}_{3}$ was observed in the density layers between 1024 and $1025 \mathrm{~kg} \mathrm{~m}^{-3}$ (shallower central water of the EUC), $\mathrm{CH}_{2} \mathrm{Br}_{2}$ was often also elevated in the denser, deeper layers below $30 \mathrm{~m}$ (Table 3). The maxima of both compounds were mostly in the vicinity of the $T$ Chl $a$ maximum. Results of the PCA (Fig. 5) also show the dissimilarity of $\mathrm{CHBr}_{3}$ and $\mathrm{CH}_{2} \mathrm{Br}_{2}$ at depth: while the variance of $\mathrm{CHBr}_{3}$ seems comparable to salinity and several phytoplankton groups such as chrysophytes, $\mathrm{CH}_{2} \mathrm{Br}_{2}$ shows many similarities with the distribution of $\mathrm{CH}_{2} \mathrm{I}_{2}$ in the water column.

\subsection{2 $\mathrm{CH}_{3} \mathrm{I}$ and $\mathrm{CH}_{2} \mathrm{I}_{2}$}

In agreement with $\mathrm{CHBr}_{3}$ and $\mathrm{CH}_{2} \mathrm{Br}_{2}, \mathrm{CH}_{3} \mathrm{I}$ was elevated in the surface (three profiles 4, 6, 7; Table 4, Fig. 3b) with values of up to $12.8 \mathrm{pmol} \mathrm{L}^{-1}$, and also elevated in the deeper layers in and below the mixed layer (Fig. 3f), reaching up to $8.5 \mathrm{pmol} \mathrm{L}^{-1}$. Most maxima of $\mathrm{CH}_{3} \mathrm{I}$ were observed closer to the surface within the mixed layer (Fig. 4d). The PCA of $\mathrm{CH}_{3} \mathrm{I}$ revealed that its variance was similar to the variance of dinoflagellates and temperature (Fig. 5).

$\mathrm{CH}_{2} \mathrm{I}_{2}$ was always depleted in the surface. Maxima of $\mathrm{CH}_{2} \mathrm{I}_{2}$ were found in different depths, sometimes associated with the $T \mathrm{Chl} a$ maximum (Fig. 3f), and mostly below the 


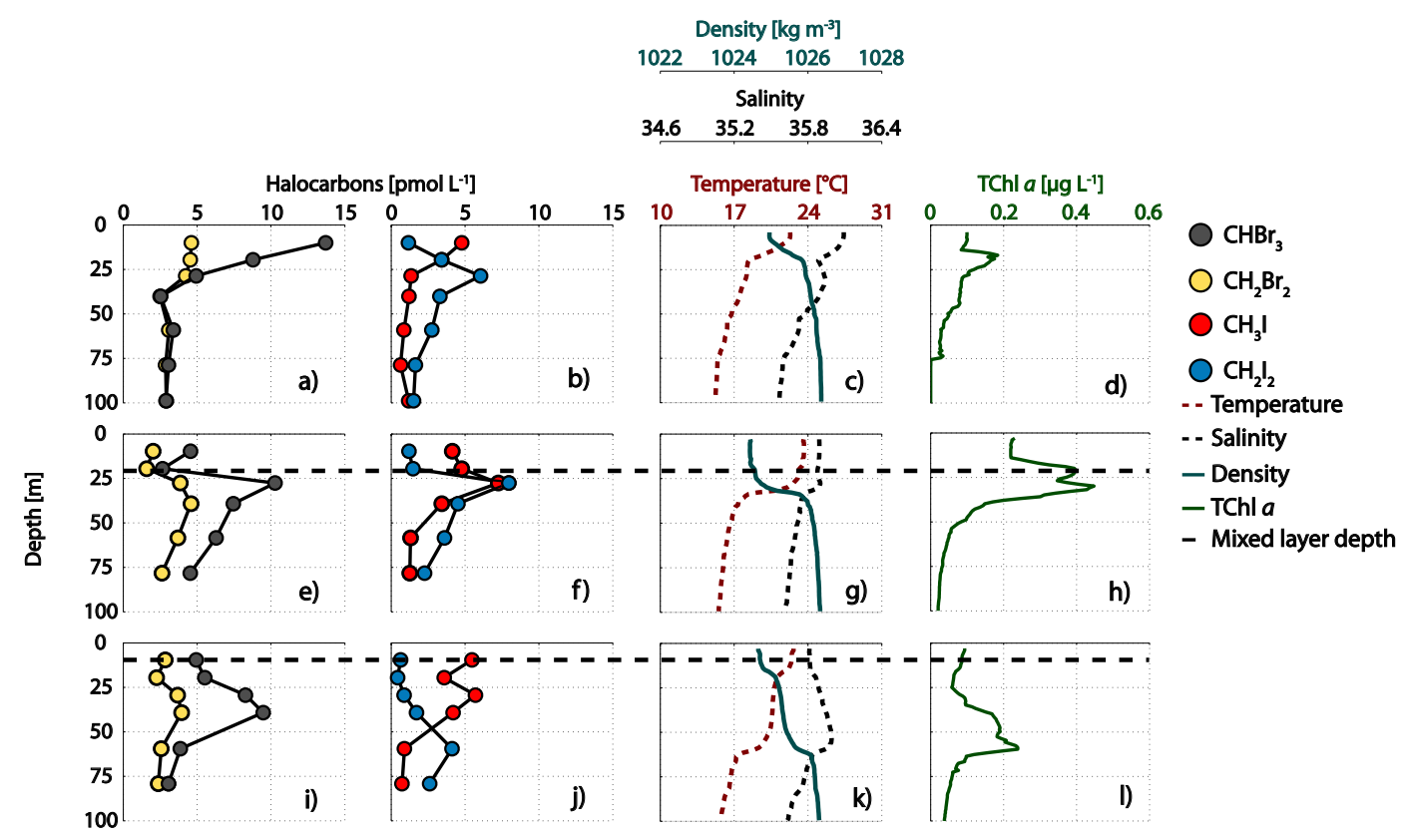

Figure 3. Selected CTD profiles (top - down: profiles 7, 9 and 10, see Fig. 1 for the location) of $\mathrm{CHBr}_{3}, \mathrm{CH}_{2} \mathrm{Br}_{2}, \mathrm{CH}_{3} \mathrm{I}$, and $\mathrm{CH}_{2} \mathrm{I}_{2}$ in $(\mathbf{a}-\mathbf{b}$, e-f), and (i-j), along with temperature, salinity, and density (c, g, k), as well as $T$ Chl $a$ in (d), (h), and (l), and the mixed layer depth as black dashed line at the same stations.

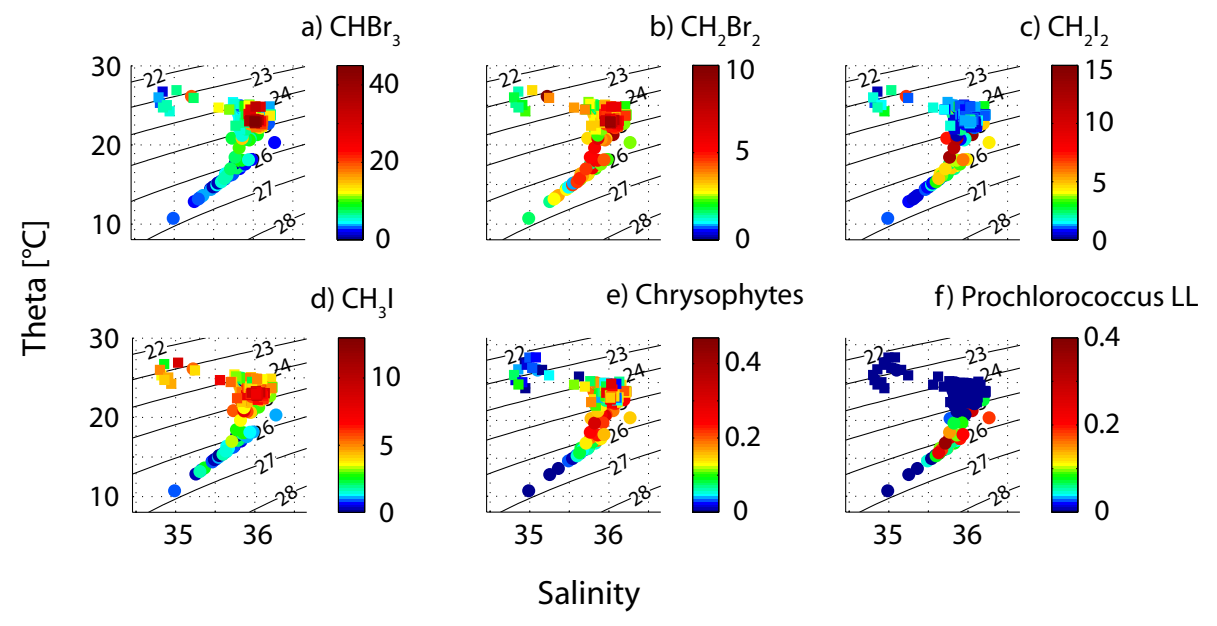

Figure 4. (a-d) Temperature-Salinity (T-S) plots for halocarbons (in pmol L ${ }^{-1}$ ) and (e-f) phytoplankton species (in $\mu \mathrm{g} \mathrm{Chl} a \mathrm{~L}^{-1}$ ). Square markers indicate surface values of halocarbons from underway measurements, circles are depth measurements from CTD profile, and the lines indicate the potential density -1000 .

mixed layer (Fig. 3j). The maxima in deeper depths appeared concurrently with the deeper $\mathrm{CH}_{2} \mathrm{Br}_{2}$ maxima (Fig. 4), which is also expressed in the PCA (Fig. 5). Values were generally much higher in deeper depths with e.g. $13.8 \mathrm{pmol} \mathrm{L}^{-1}$ between 60 and $100 \mathrm{~m}$ at profile 5 . The highest concentrations of the whole cruise of $16.0 \mathrm{pmol} \mathrm{L}^{-1}$ (profile 1) were found between 30 and $60 \mathrm{~m}$. Concentrations of only up to $12.0 \mathrm{pmol} \mathrm{L}^{-1}$ were found between 0 and $30 \mathrm{~m}$ (profile 6; Table 4).

\subsection{Fluxes}

\subsection{1 $\mathrm{CHBr}_{3}$ and $\mathrm{CH}_{2} \mathrm{Br}_{2}$}

Sea-to-air fluxes of $\mathrm{CHBr}_{3}$ and $\mathrm{CH}_{2} \mathrm{Br}_{2}$ of $644(-146-$ 4285) and $187(-3-762) \mathrm{pmol} \mathrm{m}^{-2} \mathrm{~h}^{-1}$ during MSM18/3 were larger during the first two western NS-transects of the cruise which were characterized by higher seawater concentrations, as well as higher wind speeds (Table 1, Fig. 6). Carpenter et al. (2009) and Hepach et al. (2014) reported -150 


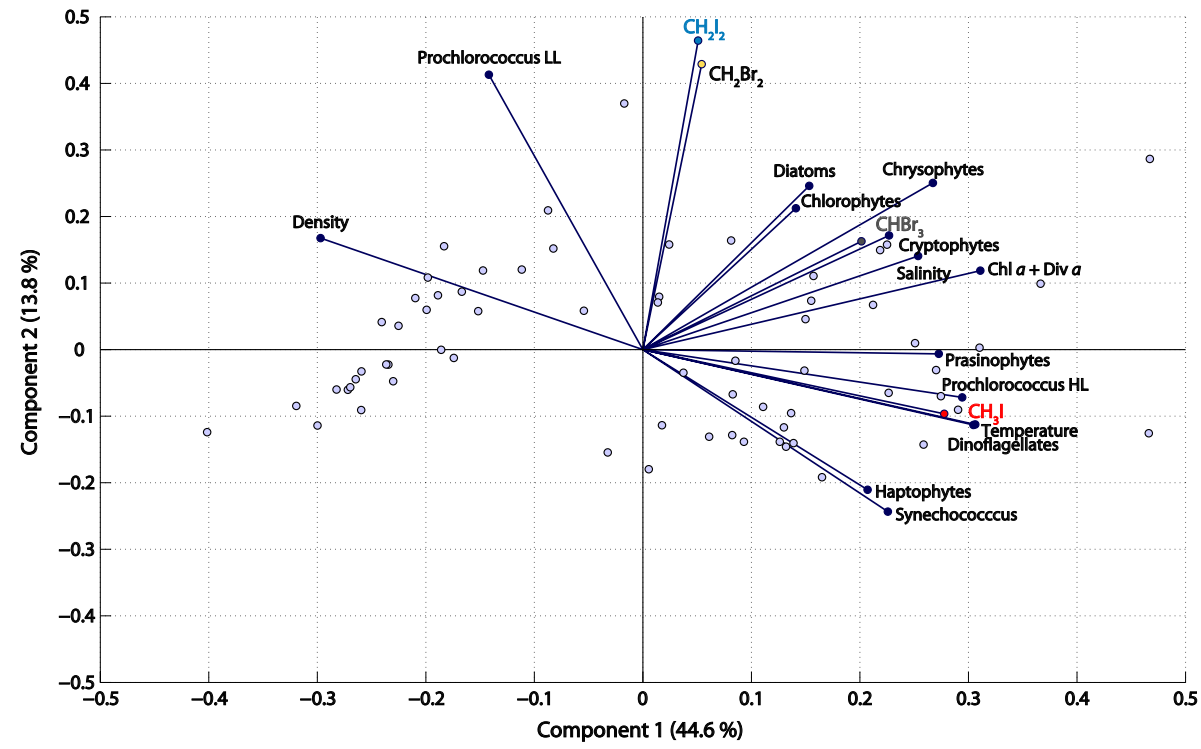

Figure 5. Principal component analysis (PCA) of halocarbon and phytoplankton species composition data, as well as temperature, salinity, and density for the 13 CTD stations during MSM18/3.

Table 4. Concentrations of $\mathrm{CH}_{3} \mathrm{I}, \mathrm{CH}_{2} \mathrm{I}_{2}$ and the sum of $T \mathrm{Chl} a$ averaged over different depths at every CTD station (1-13), as well as the mixed layer depth. If a range is not given, only one measurement point exists. Bold numbers indicate the depth of maximum concentrations at this station.

\begin{tabular}{|c|c|c|c|c|c|c|c|c|c|c|}
\hline & \multirow{3}{*}{$\begin{array}{l}z \mathrm{ML} \\
{[\mathrm{m}]}\end{array}$} & \multicolumn{3}{|c|}{$0-30 \mathrm{~m}$} & \multicolumn{3}{|c|}{$30-60 \mathrm{~m}$} & \multicolumn{3}{|c|}{$60-100 \mathrm{~m}$} \\
\hline & & \multicolumn{2}{|c|}{$\begin{array}{l}\text { Concentrations } \\
{\left[\mathrm{pmol} \mathrm{L}^{-1}\right]}\end{array}$} & \multirow[t]{2}{*}{$\begin{array}{l}T \text { Chl } a \\
{\left[\mu \mathrm{L} \mathrm{L}^{-1}\right]}\end{array}$} & \multicolumn{2}{|c|}{$\begin{array}{l}\text { Concentrations } \\
{\left[\mathrm{pmol} \mathrm{L}^{-1}\right]}\end{array}$} & \multirow[t]{2}{*}{$\begin{array}{l}T \text { Chl } a \\
{\left[\mu \mathrm{L}^{-1}\right]}\end{array}$} & \multicolumn{2}{|c|}{$\begin{array}{c}\text { Concentrations } \\
{\left[\mathrm{pmol} \mathrm{L}^{-1}\right]}\end{array}$} & \multirow[t]{2}{*}{$\begin{array}{l}T \mathrm{Chl} a \\
{\left[\mu \mathrm{L} \mathrm{L}^{-1}\right]}\end{array}$} \\
\hline & & $\mathrm{CH}_{3} \mathrm{I}$ & $\mathrm{CH}_{2} \mathrm{I}_{2}$ & & $\mathrm{CH}_{3} \mathrm{I}$ & $\mathrm{CH}_{2} \mathrm{I}_{2}$ & & $\mathrm{CH}_{3} \mathrm{I}$ & $\mathrm{CH}_{2} \mathrm{I}_{2}$ & \\
\hline 1 & 34 & $\begin{array}{l}2.7 \\
(2.1-3.4)\end{array}$ & $\begin{array}{l}4.5 \\
(1.2-6.8)\end{array}$ & $\begin{array}{l}0.60 \\
(0.52-0.69)\end{array}$ & $\begin{array}{l}2.5 \\
(1.8-3.2)\end{array}$ & $\begin{array}{l}9.9 \\
(3.9-16.0)\end{array}$ & $\begin{array}{l}0.59 \\
(0.53-0.65)\end{array}$ & 0.2 & 1.7 & - \\
\hline 2 & 16 & $\begin{array}{l}2.8 \\
(0.4-5.2)\end{array}$ & $\begin{array}{l}4.8 \\
(1.7-8.0)\end{array}$ & $\begin{array}{l}0.92 \\
(0.76-1.07)\end{array}$ & $\begin{array}{l}3.1 \\
(2.7-3.6)\end{array}$ & $\begin{array}{l}12.2 \\
(11.5-12.9)\end{array}$ & $\begin{array}{l}0.86 \\
(0.74-0.97)\end{array}$ & $\begin{array}{l}0.6 \\
(0.1-1.3)\end{array}$ & $\begin{array}{l}2.0 \\
(0.7-4.3)\end{array}$ & $\begin{array}{l}0.20 \\
(0.10-0.30)\end{array}$ \\
\hline 3 & 37 & $\begin{array}{l}8.5 \\
(8.4-8.5)\end{array}$ & $\begin{array}{l}4.1 \\
(1.7-6.4)\end{array}$ & $\begin{array}{l}0.80 \\
(0.75-0.86)\end{array}$ & $\begin{array}{l}2.6 \\
(1.0-3.5)\end{array}$ & $\begin{array}{l}4.6 \\
(4.3-4.9)\end{array}$ & $\begin{array}{l}0.65 \\
(0.51-0.80)\end{array}$ & $\begin{array}{l}0.7 \\
(0.4-1.1)\end{array}$ & $\begin{array}{l}3.3 \\
(2.3-4.4)\end{array}$ & 0.18 \\
\hline 4 & 14 & $\begin{array}{l}6.1 \\
(5.5-6.6)\end{array}$ & 7.0 & $\begin{array}{l}0.56 \\
(0.26-0.86)\end{array}$ & $\begin{array}{l}4.6 \\
(4.6-4.7)\end{array}$ & $\begin{array}{l}2.3 \\
(2.2-2.4)\end{array}$ & $\begin{array}{l}0.80 \\
(0.79-0.81)\end{array}$ & $\begin{array}{l}0.8 \\
(0.7-0.9)\end{array}$ & $\begin{array}{l}1.0 \\
(0.7-1.3)\end{array}$ & $\begin{array}{l}0.19 \\
(0.13-0.26)\end{array}$ \\
\hline 5 & 49 & 5.4 & $\begin{array}{l}0.6 \\
(0.5-0.7)\end{array}$ & $\begin{array}{l}0.34 \\
(0.28-0.39)\end{array}$ & 4.5 & 4.9 & 0.58 & $\begin{array}{l}2.4 \\
(1.9-3.0)\end{array}$ & $\begin{array}{l}10.5 \\
(7.1-13.8)\end{array}$ & $\begin{array}{l}0.39 \\
(0.24-0.53)\end{array}$ \\
\hline 6 & 12 & $\begin{array}{l}10.4 \\
(8.0-12.8)\end{array}$ & $\begin{array}{l}6.9 \\
(1.8-12.0)\end{array}$ & 0.99 & $\begin{array}{l}1.6 \\
(1.5-1.7)\end{array}$ & $\begin{array}{l}4.0 \\
(3.1-4.8)\end{array}$ & $\begin{array}{l}0.30 \\
(0.17-0.43)\end{array}$ & $\begin{array}{l}1.4 \\
(1.0-1.7)\end{array}$ & $\begin{array}{l}2.4 \\
(1.7-3.1)\end{array}$ & $\begin{array}{l}0.10 \\
(0.04-0.17)\end{array}$ \\
\hline 7 & - & $\begin{array}{l}4.1 \\
(3.4-4.8)\end{array}$ & $\begin{array}{l}2.3 \\
(1.2-3.4)\end{array}$ & $\begin{array}{l}0.71 \\
(0.65-0.76)\end{array}$ & $\begin{array}{l}1.3 \\
(1.2-1.3)\end{array}$ & $\begin{array}{l}4.7 \\
(3.3-6.1)\end{array}$ & $\begin{array}{l}0.46 \\
(0.44-0.48)\end{array}$ & $\begin{array}{l}0.9 \\
(0.6-1.2)\end{array}$ & $\begin{array}{l}2.0 \\
(1.5-2.7)\end{array}$ & $\begin{array}{l}0.11 \\
(0.06-0.17)\end{array}$ \\
\hline 8 & 45 & $\begin{array}{l}0.2 \\
(0.1-0.4)\end{array}$ & $\begin{array}{l}0.3 \\
(0.3-0.3)\end{array}$ & $\begin{array}{l}0.34 \\
(0.31-0.38)\end{array}$ & $\begin{array}{l}4.7 \\
(3.0-7.0)\end{array}$ & $\begin{array}{l}1.2 \\
(0.5-1.9)\end{array}$ & $\begin{array}{l}0.51 \\
(0.47-0.58)\end{array}$ & 0.0 & 2.4 & 0.51 \\
\hline 9 & 21 & $\begin{array}{l}4.4 \\
(4.1-4.8)\end{array}$ & $\begin{array}{l}1.3 \\
(1.2-1.5)\end{array}$ & $\begin{array}{l}0.75 \\
(0.64-0.85)\end{array}$ & $\begin{array}{l}5.3 \\
(3.4-7.3)\end{array}$ & $\begin{array}{l}6.2 \\
(4.5-8.0)\end{array}$ & $\begin{array}{l}0.77 \\
(0.68-0.85)\end{array}$ & $\begin{array}{l}1.3 \\
(1.3-1.3)\end{array}$ & $\begin{array}{l}2.9 \\
(2.3-3.6)\end{array}$ & $\begin{array}{l}0.24 \\
(0.17-0.32)\end{array}$ \\
\hline 10 & 10 & $\begin{array}{l}4.5 \\
(3.6-5.5)\end{array}$ & $\begin{array}{l}0.5 \\
(0.4-0.6)\end{array}$ & $\begin{array}{l}0.50 \\
(0.41-0.59)\end{array}$ & $\begin{array}{l}4.9 \\
(4.2-5.7)\end{array}$ & $\begin{array}{l}1.3 \\
(0.9-1.7)\end{array}$ & $\begin{array}{l}0.62 \\
(0.51-0.73)\end{array}$ & $\begin{array}{l}0.8 \\
(0.7-0.9)\end{array}$ & $\begin{array}{l}3.4 \\
(2.6-4.1)\end{array}$ & $\begin{array}{l}0.47 \\
(0.32-0.62)\end{array}$ \\
\hline 11 & 24 & $\begin{array}{l}3.8 \\
(2.9-4.6)\end{array}$ & 0.4 & $\begin{array}{l}0.46 \\
(0.42-0.49)\end{array}$ & 4.4 & 2.3 & 0.82 & $\begin{array}{l}1.7 \\
(1.0-2.3)\end{array}$ & $\begin{array}{l}1.7 \\
(0.6-3.2)\end{array}$ & $\begin{array}{l}0.23 \\
(0.04-0.44)\end{array}$ \\
\hline 12 & 35 & $\begin{array}{l}7.0 \\
(6.8-7.1)\end{array}$ & $\begin{array}{l}1.2 \\
(0.3-2.2)\end{array}$ & $\begin{array}{l}0.77 \\
(0.76-0.79)\end{array}$ & 2.7 & $\begin{array}{l}4.1 \\
(3.8-4.3)\end{array}$ & $\begin{array}{l}0.70 \\
(0.68-0.72)\end{array}$ & 2.0 & $\begin{array}{l}2.7 \\
(1.6-3.8)\end{array}$ & 0.25 \\
\hline 13 & 41 & $\begin{array}{l}5.1 \\
(4.3-5.9)\end{array}$ & $\begin{array}{l}1.5 \\
(0.8-2.1)\end{array}$ & $\begin{array}{l}0.55 \\
(0.51-0.58)\end{array}$ & $\begin{array}{l}3.8 \\
(2.0-5.6)\end{array}$ & $\begin{array}{l}5.9 \\
(3.9-7.4)\end{array}$ & $\begin{array}{l}0.16 \\
(0-0.48)\end{array}$ & $\begin{array}{l}1.0 \\
(0.1-2.0)\end{array}$ & $\begin{array}{l}3.4 \\
(1.0-4.8)\end{array}$ & $\begin{array}{l}0.12 \\
(0-0.30)\end{array}$ \\
\hline
\end{tabular}

and $3504 \mathrm{pmol} \mathrm{m}^{-2} \mathrm{~h}^{-1} \mathrm{CHBr}_{3}$ fluxes as well as of 5-917 for $\mathrm{CH}_{2} \mathrm{Br}_{2}$ from the Cape Verde and Mauritanian upwelling region. The lower fluxes in the equatorial region are a result of the lower wind speeds measured during MSM18/3, ranging from $0.3-11.1$ with a mean of $6.1 \mathrm{~m} \mathrm{~s}^{-1}$, and the lower concentration gradients in comparison to Carpenter et al. (2009). Quack et al. (2004) reported $\mathrm{CHBr}_{3}$ fluxes from the equato- rial Atlantic of $2700( \pm 800) \mathrm{pmol} \mathrm{m}^{-2} \mathrm{~h}^{-1}$, which compare well to this study.

Diapycnal fluxes are the fluxes of halocarbons that diffuse out or into the mixed layer from below the thermocline. Maxima within the mixed layer will lead to fluxes towards the thermocline, while maxima below the mixed layer will result in a flux of halocarbon-molecules into the mixed layer. Diapycnal fluxes of halocarbons were generally low although 


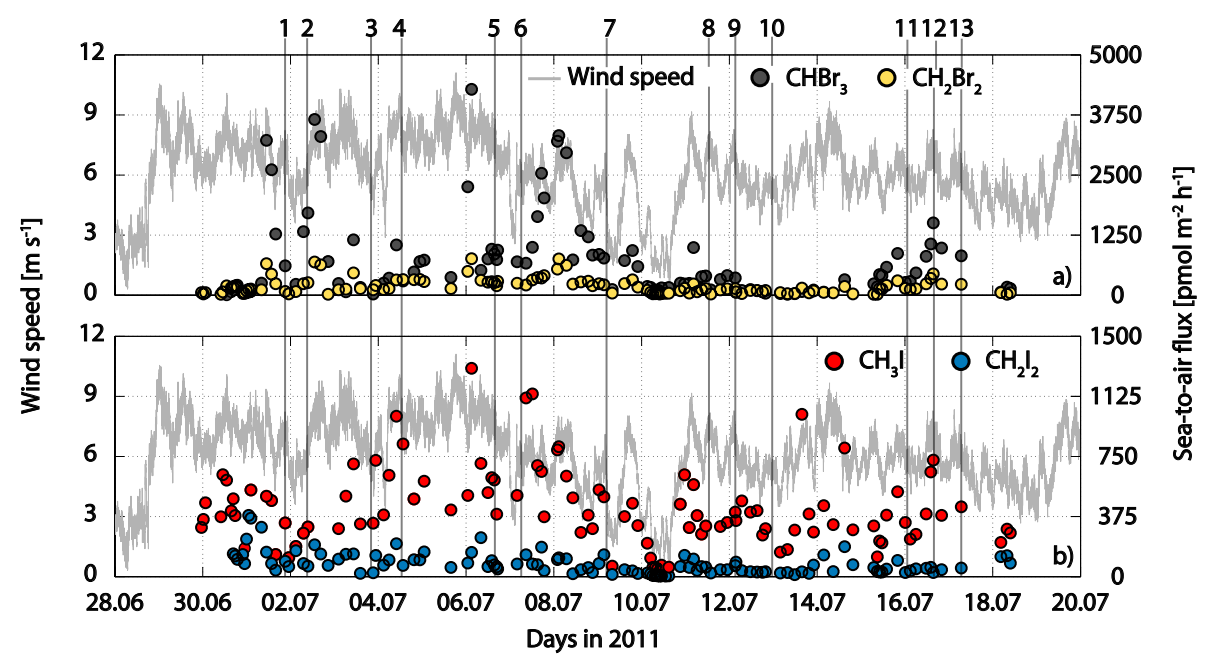

Figure 6. Wind speed during the cruise and sea-to-air fluxes calculated with sea surface water concentrations and mean atmospheric halocarbon data (a) $\mathrm{CHBr}_{3}$ and $\mathrm{CH}_{2} \mathrm{Br}_{2}$ and (b) $\mathrm{CH}_{3} \mathrm{I}$ and $\mathrm{CH}_{2} \mathrm{I}_{2}$. Numbers on the top indicate CTD station.

the EUC can lead to enhanced mixing. This is due to the comparably small concentration gradients of the halocarbons. Diapycnal fluxes were $80\left(\mathrm{CHBr}_{3}\right)$ to 200 times $\left(\mathrm{CH}_{2} \mathrm{Br}_{2}\right)$ lower than sea-to-air fluxes (Table 5). They acted both as a source and a sink for halocarbons in the mixed layer. At eight stations, $\mathrm{CHBr}_{3}$ was diffusing into the mixed layer, providing on average $5(0-14) \mathrm{pmol} \mathrm{m}^{-2} \mathrm{~h}^{-1}$ from below to the mixed layer budget of $\mathrm{CHBr}_{3}$. On the other hand, on average 30 (2-125) $\mathrm{pmol} \mathrm{m}^{-2} \mathrm{~h}^{-1}$ were diffusing out of the mixed layer, which is the highest flux to the thermocline of all four halocarbons, as a result of its large concentration gradients across the bottom of the mixed layer. Diapycnal fluxes of $\mathrm{CH}_{2} \mathrm{Br}_{2}$ were generally lower than for $\mathrm{CHBr}_{3}$ due to its lower concentration gradients. Its fluxes into the mixed layer from eight profiles were on average $3(0-8) \mathrm{pmol} \mathrm{m}^{-2} \mathrm{~h}^{-1}$, while the diapycnal flux reduced the mixed layer budget of $\mathrm{CH}_{2} \mathrm{Br}_{2}$ by 2 $(0-8) \mathrm{pmol} \mathrm{m}^{-2} \mathrm{~h}^{-1}$ at the remaining five stations.

\subsection{2 $\mathrm{CH}_{3} \mathrm{I}$ and $\mathrm{CH}_{2} \mathrm{I}_{2}$}

$\mathrm{CH}_{3} \mathrm{I}$ sea-to-air fluxes were on average 425 (341300) $\mathrm{pmol} \mathrm{m}^{-2} \mathrm{~h}^{-1}$ during the cruise. During the eastern NS-transects, fluxes were elevated at several locations mostly during daytime in contrast to the bromocarbons, in accordance with a larger concentration gradient of $\mathrm{CH}_{3} \mathrm{I}$ in that region (Table 1, Fig. 6). The fluxes are only half of the sea-to-air fluxes from the equatorial Atlantic region reported by Richter and Wallace (2004) of $958 \pm 750 \mathrm{pmol} \mathrm{m}^{-2} \mathrm{~h}^{-1}$ and a fifth of the fluxes reported from Jones et al. (2010) of on average $2154 \mathrm{pmol} \mathrm{m}^{-2} \mathrm{~h}^{-1}$ from the Cape Verde and Mauritanian upwelling region. But, they were two times larger than the fluxes of Hepach et al. (2014) of on average $246 \mathrm{pmol} \mathrm{m}^{-2} \mathrm{~h}^{-1}$. $\mathrm{CH}_{2} \mathrm{I}_{2}$ fluxes were generally larger in the beginning of the cruise where higher wind speeds and higher surface water concentrations existed. Only few studies have published sea-to-air fluxes of $\mathrm{CH}_{2} \mathrm{I}_{2}$ from the tropical ocean. $\mathrm{CH}_{2} \mathrm{I}_{2}$ emissions calculated for MSM18/3 are with only $82(3-382) \mathrm{pmol} \mathrm{m}^{-2} \mathrm{~h}^{-1}$ very low in comparison to mean fluxes reported by Jones et al. (2010) of on average 541-688 $\mathrm{pmol} \mathrm{m}^{-2} \mathrm{~h}^{-1}$, which are the result of higher oceanic $\mathrm{CH}_{2} \mathrm{I}_{2}$ (Jones et al., 2010).

Similar to the bromocarbons, diapycnal fluxes of $\mathrm{CH}_{3} \mathrm{I}$ and $\mathrm{CH}_{2} \mathrm{I}_{2}$ were generally lower (117 and 7 times, respectively) than sea-to-air fluxes (Table 5). Due to the larger $\mathrm{CH}_{3} \mathrm{I}$ concentrations in the mixed layer compared to the upper thermocline, diapycnal fluxes of $5(1-13) \mathrm{pmol} \mathrm{m}^{-2} \mathrm{~h}^{-1}$ were mostly acting as a sink for the mixed layer budget. Only at three stations, $2(1-5) \mathrm{pmol} \mathrm{m}^{-2} \mathrm{~h}^{-1}$ were transported into the mixed layer. Diapycnal fluxes of $\mathrm{CH}_{2} \mathrm{I}_{2}$ acted mostly as source for the mixed layer, providing on average $12(0-$ 39) $\mathrm{pmol} \mathrm{m}^{-2} \mathrm{~h}^{-1}$ due to its much higher concentrations in the water below. This represents the highest halocarbon flux of the four compounds into the mixed layer. The diapycnal flux of $\mathrm{CH}_{2} \mathrm{I}_{2}$ of $2(0-4) \mathrm{pmol} \mathrm{m}^{-2} \mathrm{~h}^{-1}$ out of the mixed layer was only observed at three stations.

\section{Discussion}

\subsection{Surface water distribution}

\subsection{1 $\mathrm{CHBr}_{3}$ and $\mathrm{CH}_{2} \mathrm{Br}_{2}$}

The equatorial Atlantic is a source of $\mathrm{CHBr}_{3}$ and $\mathrm{CH}_{2} \mathrm{Br}_{2}$ to the atmosphere during the ACT season, and the correlations of their water concentrations to biogenic parameters indicate biological formation. $\mathrm{CHBr}_{3}$ and $\mathrm{CH}_{2} \mathrm{Br}_{2}$ correlated significantly, but weakly with $T \mathrm{Chl} a$, which is not an unusual feature (Abrahamsson et al., 2004a; Carpenter et al., 2009; Liu et al., 2011; Hepach et al., 2014). It has been suggested 
Table 5. Diapycnal and sea-to-air fluxes at every CTD station for the four halocarbons. Positive fluxes in bold provide the mixed layer with the corresponding halocarbon, while negative fluxes indicate losses from the mixed layer.

\begin{tabular}{|c|c|c|c|c|c|c|c|c|}
\hline \multirow[t]{2}{*}{ CTD station } & \multicolumn{2}{|c|}{$\mathrm{CHBr}_{3}$} & \multicolumn{2}{|c|}{$\mathrm{CH}_{2} \mathrm{Br}_{2}$} & \multicolumn{2}{|c|}{$\mathrm{CH}_{3} \mathrm{I}$} & \multicolumn{2}{|c|}{$\mathrm{CH}_{2} \mathrm{I}_{2}$} \\
\hline & $\begin{array}{l}\text { Diapycnal flux } \\
{\left[\mathrm{pmol} \mathrm{m}^{-2} \mathrm{~h}^{-1}\right]}\end{array}$ & $\begin{array}{r}\text { Sea-to-air flux } \\
{\left[\mathrm{pmol} \mathrm{m}^{-2} \mathrm{~h}^{-1}\right]}\end{array}$ & $\begin{array}{r}\text { Diapycnal flux } \\
{\left[\mathrm{pmol} \mathrm{m}^{-2} \mathrm{~h}^{-1}\right]}\end{array}$ & $\begin{array}{r}\text { Sea-to-air flux } \\
{\left[\mathrm{pmol} \mathrm{m}^{-2} \mathrm{~h}^{-1}\right]}\end{array}$ & $\begin{array}{r}\text { Diapycnal flux } \\
{\left[\mathrm{pmol} \mathrm{m}{ }^{-2} \mathrm{~h}^{-1}\right]}\end{array}$ & $\begin{array}{r}\text { Sea-to-air flux } \\
{\left[\mathrm{pmol} \mathrm{m}{ }^{-2} \mathrm{~h}^{-1}\right]}\end{array}$ & $\begin{array}{r}\text { Diapycnal flux } \\
{\left[\mathrm{pmol} \mathrm{m}^{-2} \mathrm{~h}^{-1}\right]}\end{array}$ & $\begin{array}{r}\text { Sea-to-air flux } \\
{\left[\mathrm{pmol} \mathrm{m}{ }^{-2} \mathrm{~h}^{-1}\right]}\end{array}$ \\
\hline 1 & 14 & 14 & 8 & -27 & 5 & -119 & 39 & -64 \\
\hline 2 & -125 & -3651 & -8 & -689 & -13 & -44 & 29 & -199 \\
\hline 3 & 0 & -184 & 1 & -195 & -6 & -703 & 7 & -129 \\
\hline 4 & 8 & -241 & 4 & -265 & -1 & -671 & 3 & - \\
\hline 5 & -43 & -893 & 4 & -275 & -42 & - & 9 & -45 \\
\hline 6 & 5 & -4590 & 7 & -185 & -13 & -988 & 27 & -121 \\
\hline 7 & - & - & - & - & - & - & - & - \\
\hline 8 & -2 & -110 & -0 & -25 & -1 & -4 & 0 & -22 \\
\hline 9 & 3 & -57 & 1 & -64 & 1 & -337 & 3 & -88 \\
\hline 10 & 2 & -45 & -2 & -83 & -6 & -300 & -1 & -30 \\
\hline 11 & 4 & -248 & 1 & -136 & 1 & -316 & 0 & -24 \\
\hline 12 & -4 & -1208 & -1 & -357 & -2 & -583 & -0 & -20 \\
\hline 13 & 1 & -837 & 0 & -231 & -3 & -446 & -4 & -54 \\
\hline
\end{tabular}

that $\mathrm{CHBr}_{3}$ is not produced directly from phytoplankton, but rather from dissolved organic matter (DOM) present in sea water (Lin and Manley, 2012). This was more closely investigated in laboratory experiments by Liu et al. (2015), who suggested that the weak in situ correlations of bromocarbons with $\mathrm{Chl} a$ are a result of this indirect production pathway. The correlation with certain phytoplankton groups may then be caused by the production of phytoplankton-specific DOM. The very negative correlations of bromocarbons with SST and positive correlations with SSS indicate a relationship of bromocarbon abundance with processes within the cold and nutrient-rich upwelled water of the EUC (Sect. 3.2), supported by the T-S diagrams (Fig. 4). Weak, but significant negative correlations with latitude $\left(r_{\mathrm{s}}=-0.38\right.$ for $\mathrm{CHBr}_{3}$ and $r_{\mathrm{s}}=-0.18$ for $\mathrm{CH}_{2} \mathrm{Br}_{2}$ ) and maximum values of the bromocarbons between 2 and $3^{\circ} \mathrm{S}$, where EUC water reaches the surface, underline this hypothesis. Although the correlation analysis of halocarbons with phytoplankton groups cannot directly resolve production and loss processes by algal activity, it is still an indicator for possible involvement of these species in halocarbon production. Bromocarbon production might exceed loss processes, which leads to the observed statistical link of $\mathrm{CHBr}_{3}$ and $\mathrm{CH}_{2} \mathrm{Br}_{2}$ to chrysophytes. Chrysophytes are to our knowledge not yet among observed halocarbon producers in incubation and field studies. The strong negative correlations of Prochlorococcus HL with $\mathrm{CHBr}_{3}$ and $\mathrm{CH}_{2} \mathrm{Br}_{2}$ have been observed previously (Hepach et al., 2014). These significant negative correlations can be explained by the large abundance of Prochlorococcus in warm water while bromocarbons on the other hand are more correlated with the cooler water of the EUC, which is richer in nutrients and chrysophytes, haptophytes and dinoflagellates.

\subsection{2 $\mathrm{CH}_{3} \mathrm{I}$ and $\mathrm{CH}_{2} \mathrm{I}_{2}$}

$\mathrm{CH}_{3} \mathrm{I}$ concentrations and wind speed were weakly anticorrelated during MSM18/3. Richter (2004) interprets this as depletion of the surface concentrations, when air-sea fluxes exceed the production rate during high wind speed. There are two production mechanisms suggested for $\mathrm{CH}_{3} \mathrm{I}$. Previous studies (Richter and Wallace, 2004; Jones et al., 2010) have attributed $\mathrm{CH}_{3} \mathrm{I}$ in the tropical ocean mainly to photochemical formation based on the observations of Moore and Zafiriou (1994). In contrast to these studies, indications for biological formation of $\mathrm{CH}_{3} \mathrm{I}$ were found in the ACT region during our study. $\mathrm{CH}_{3} \mathrm{I}$ showed a weak negative correlation with SST, significant correlations with the biologically produced $\mathrm{CHBr}_{3}$ and $\mathrm{CH}_{2} \mathrm{Br}_{2}$ (Table 2) and with $T \mathrm{Chl} a$ as biomass indicator, and no correlation to global radiation. These imply a relationship with the biologically active upwelled water. Elevated concentrations of $\mathrm{CH}_{3} \mathrm{I}$ were found between 10 and $5^{\circ} \mathrm{W}$ during midday (see $\mathrm{CH}_{3} \mathrm{I}$ in comparison to global radiation in Fig. 2), which could be a result of photochemical formation. Thus we suggest that photochemistry and biological production likely both played a role during MSM18/3. Haptophytes correlated most significantly of the phytoplankton groups with $\mathrm{CH}_{3} \mathrm{I}$ and have already been shown to produce $\mathrm{CH}_{3} \mathrm{I}$ both in the laboratory (Itoh et al., 1997; Manley and de la Cuesta, 1997; Scarratt and Moore, 1998; Smythe-Wright et al., 2010) and in the field (Abrahamsson et al., 2004b). Correlations during MSM18/3 additionally indicate a possible involvement of $d i$ noflagellates and chrysophytes in the production of methyl iodide (Table 2). The importance of oceanic $\mathrm{CH}_{3} \mathrm{I}$ production by Prochlorochcoccus is a matter of dispute. Brownell et al. (2010) report it to be a minor source, in contrast to both Smythe-Wright et al. (2006) and Hughes et al. (2010, 2011). No evidence of involvement of Prochlorococcus HL was found during MSM18/3. 
The very low sea surface concentrations of $\mathrm{CH}_{2} \mathrm{I}_{2}$ with lowest concentrations during the day can be explained by its fast photolysis (few minutes lifetime in surface sea water) (Jones and Carpenter, 2005; Martino et al., 2005). Although $\mathrm{CH}_{2} \mathrm{I}_{2}$ is generally assumed to be of biogenic origin in the open ocean (Moore and Tokarczyk, 1993; Yamamoto et al., 2001; Orlikowska and Schulz-Bull, 2009; Hopkins et al., 2013), great uncertainties remain as to which species are involved in its production. During MSM18/3, indications were found for different source species than of the other three compounds (chlorophytes and Prochlorococcus HL).

\subsection{Water column distribution}

Halocarbon maxima in the $T \mathrm{Chl} a$ maximum, attributed to their biological production, are often observed from polar to tropical regions (Moore and Tokarczyk, 1993; Moore and Groszko, 1999; Yamamoto et al., 2001; Quack et al., 2004; Carpenter et al., 2007; Hughes et al., 2009). In contrast, photochemical formation of $\mathrm{CH}_{3} \mathrm{I}$ can lead to surface maxima (Happell and Wallace, 1996). During MSM18/3, maxima of halocarbons were not always found in the $T \mathrm{Chl} a$ maximum. This does not contradict their biological production, as the location of the $T \mathrm{Chl} a$ maximum is not necessarily the location of highest biomass or primary production, but rather reflects the photoadaption capability of the predominant phytoplankton groups (Claustre and Marty, 1995). Unfortunately, neither biomass nor primary production was measured during the cruise. Additionally, halocarbons could be produced by phytoplankton groups that are not in the maximum of the biomass distribution in the water column, and the location of the halocarbon maximum might be more determined from their sink processes than from their production. Surprisingly, the time of day, influencing sink and production processes, seemed to play a minor role for the shape of the profiles for all four compounds (see the location of the CTD stations in Fig. 2).

\subsection{1 $\mathrm{CHBr}_{3}$ and $\mathrm{CH}_{2} \mathrm{Br}_{2}$}

In contrast to their similar occurrence in the surface, $\mathrm{CHBr}_{3}$ and $\mathrm{CH}_{2} \mathrm{Br}_{2}$ showed different distributions in the water column (Fig. 5). Strong indications for biological sources of $\mathrm{CHBr}_{3}$ exist in the PCA, and chrysophytes as potential source group are in agreement to the surface water observations (Table 2, Fig. 5). Maximum $\mathrm{CH}_{2} \mathrm{Br}_{2}$ concentrations were occasionally found below the $\mathrm{CHBr}_{3}$ maxima, which have already been observed in the Mauritanian upwelling (Quack et al., 2007b). The deeper maxima may be either due to an additional source of $\mathrm{CH}_{2} \mathrm{Br}_{2}$ such as the biologically mediated conversion of $\mathrm{CHBr}_{3}$ (Hughes et al., 2013) or to a faster degradation of $\mathrm{CHBr}_{3}$ than of $\mathrm{CH}_{2} \mathrm{Br}_{2}$ at depth. Sinks for $\mathrm{CHBr}_{3}$ and $\mathrm{CH}_{2} \mathrm{Br}_{2}$ in tropical surface waters include very slow hydrolysis (hundreds to thousands of years; Mabey and Mill, 1978) and slow halogen substitution (5 years; Geen,
1992). Photolysis, which has been suggested to be faster for $\mathrm{CHBr}_{3}$ (9 years with a mixed layer of $100 \mathrm{~m}$ for $\mathrm{CHBr}_{3}$ ) than for $\mathrm{CH}_{2} \mathrm{Br}_{2}$ (Carpenter et al., 2009) would be of more significance in the surface layer. A faster degradation of $\mathrm{CHBr}_{3}$ in greater depths is also somewhat contrary to the observed very fast bacterial degradation of $\mathrm{CH}_{2} \mathrm{Br}_{2}$ with a half-live of 2 days (Goodwin et al., 1998). An additional source for $\mathrm{CH}_{2} \mathrm{Br}_{2}$ that involves $\mathrm{CHBr}_{3}$ therefore seems more plausible. At four of the 13 stations, indications for the additional source were found. There, maximum $\mathrm{CH}_{2} \mathrm{Br}_{2}$ concentrations were found below $\mathrm{CHBr}_{3}$, which could be the result of its faster conversion to $\mathrm{CH}_{2} \mathrm{Br}_{2}$ than its production. $\mathrm{CH}_{2} \mathrm{Br}_{2}$ in denser water is also co-located with Prochlorococcus LL, which might be involved in the $\mathrm{CHBr}_{3}$-conversion.

\subsection{2 $\mathrm{CH}_{3} \mathrm{I}$ and $\mathrm{CH}_{2} \mathrm{I}_{2}$}

$\mathrm{CH}_{3} \mathrm{I}$ was usually elevated in the top $30 \mathrm{~m}$ of the water column apart from three profiles, where maximum concentrations were found between 30 and $60 \mathrm{~m}$. The surface maxima, as seen in the T-S diagram (Fig. 4), support the photochemical formation of $\mathrm{CH}_{3} \mathrm{I}$ (Happell and Wallace, 1996). Deeper maxima could also arise if the sea-to-air flux exceeds the photochemical production. However, the low wind speed during the cruise (Sect. 3), the relationship with biological parameters, and the partly co-located maxima with the other three biogenic halocarbons (Figs. 3, 5) also point to a direct production of $\mathrm{CH}_{3} \mathrm{I}$ from phytoplankton. These include $d i$ noflagellates as indicated by the correlations and the PCA (Fig. 5).

$\mathrm{CH}_{2} \mathrm{I}_{2}$ was always depleted in the surface with respect to the underlying water column as a result of its strong photolysis (Jones and Carpenter, 2005; Martino et al., 2006). It was frequently elevated below the $T \mathrm{Chl} a$ maximum and below the base of the mixed layer (Fig. 3) in contrast to previous studies (Moore and Tokarczyk, 1993; Yamamoto et al., 2001). The similarity in its distribution to $\mathrm{CH}_{2} \mathrm{Br}_{2}$ (Figs. 4, 5) could indicate similar production and sink processes at depth. Bacterial formation of $\mathrm{CH}_{2} \mathrm{I}_{2}$ (Fuse et al., 2003; Amachi et al., 2005) in the upper thermocline could also be an additional source for this compound. Alternatively, $\mathrm{CH}_{2} \mathrm{I}_{2}$ may not degrade as quickly as $\mathrm{CHBr}_{3}$ and $\mathrm{CH}_{3} \mathrm{I}$ in greater depths, which would lead to its accumulation below the mixed layer.

\subsection{Factors contributing to halocarbon emissions from the mixed layer}

Halocarbon emissions into the atmosphere depend strongly on the mixed layer budget of these compounds, which is determined by their sources and sinks. It is unclear where the main halocarbon production occurs. It has been suggested that it mainly takes place in the subsurface $T$ Chl $a$ maximum (Quack et al., 2004; Martino et al., 2006), whereas other model studies assume production of, e.g., $\mathrm{CHBr}_{3}$ to be coupled to primary production in the whole water column 
(Hense and Quack, 2009). Assuming production of halocarbons takes place mainly in the $T \mathrm{Chl} a$ maximum, which is often located below the mixed layer, diapycnal fluxes from below the thermocline will be the most important source for mixed layer halocarbons.

\subsubsection{Transport and loss processes in the mixed layer}

To evaluate the significance of halocarbon production below the mixed layer for emissions into the atmosphere, production, loss and transport processes have to be considered. The diapycnal fluxes of the four halocarbons were calculated from 13 halocarbon profiles and parallel measurements of eddy diffusivity (Sect. 4.3). The data are characterized by a low depth resolution of the halocarbons within the water column and a short validity of the diffusion coefficients, which make the diapycnal fluxes subject to some uncertainties. Given that the depth profiles measured during MSM18/3 agree well to previous studies from the tropical ocean (Yamamoto et al., 2001; Quack et al., 2004), a general idea of the significance of diapycnal fluxes for the mixed layer budget of halocarbons can be obtained. The chemical loss rates are estimated from published data which include hydrolysis, halogen substitution and photolysis. The half-lives of $\mathrm{CHBr}_{3}$ and $\mathrm{CH}_{2} \mathrm{Br}_{2}$ due to hydrolysis are hundreds to thousands of years (Mabey and Mill, 1978), while for $\mathrm{CH}_{3} \mathrm{I}$, the half-life due to hydrolysis ranges from 1600 days at $25^{\circ} \mathrm{C}$ to 4000 days at $5^{\circ} \mathrm{C}$ (Elliott and Rowland, 1995). The half-life of $\mathrm{CHBr}_{3}$ with respect to photolysis is 9 years assuming a mixed-layer depth of $100 \mathrm{~m}$ and is potentially longer for $\mathrm{CH}_{2} \mathrm{Br}_{2}$. Liu et al. (2011) calculated the half-life of $\mathrm{CHBr}_{3}$ due to photolysis in a coastal mixed layer of $5 \mathrm{~m}$ to be only 82 days. Mixed layers during MSM18/3 were from surface down to $49 \mathrm{~m}$, photolysis of bromocarbons in the mixed layer will lead to half-lives of several months. Sea-to-air flux is the most significant sink for $\mathrm{CHBr}_{3}$ and $\mathrm{CH}_{2} \mathrm{Br}_{2}$ from the mixed layer. Mean half-lives of 8 days were calculated for both compounds during MSM18/3, based on the fluxes (Sect. 4.3.1) and the mixed layer depths during the cruise (Table 3). We consider a very short timescale of $1 \mathrm{~h}$ for our budget calculations due to the validity of the diapycnal flux coefficients, while the general findings of our calculations are also valid for a longer timescale. As the sink from the mixed layer due to sea-to-air fluxes is a magnitude larger than the other mentioned sinks, we will neglect them in our estimates for $\mathrm{CHBr}_{3}$ and $\mathrm{CH}_{2} \mathrm{Br}_{2}$ as they do not play a large role. Photolysis of $\mathrm{CH}_{3} \mathrm{I}$ is very slow in comparison to halide substitution (Zika et al., 1984). The latter is suggested to be an important sink in the tropical ocean during low wind speeds (Jones and Carpenter, 2007), while large wind speeds favour seato-air fluxes as main sink (mean half-life of 8 days during MSM18/3). All three sink processes are included in our budget estimates using the rates published by Elliott and Rowland (1993). For $\mathrm{CH}_{2} \mathrm{I}_{2}$, photolysis is the most significant sink in surface water (Jones and Carpenter, 2005). In our cal- culations, losses of $\mathrm{CH}_{2} \mathrm{I}_{2}$ due to photolysis were calculated according to Martino et al. (2006) with a photon flux calculated from the NASA COART model (Jin et al., 2006), a $T$ Chl $a$ concentration of $0.4 \mu \mathrm{g} \mathrm{L}^{-1}$, absolute quantum yields from Martino et al. (2006), and absorption cross sections determined by Jones and Carpenter (2005).

\subsubsection{Mixed layer budget of halocarbons during MSM18/3}

In the following section, the results of the halocarbon budget calculations are presented. The total mixed layer concentrations were calculated at every station considering a water column with a volume of $1 \times 1 \times z_{\mathrm{ML}} \mathrm{m}^{3}$. Assuming that halocarbons are only produced below the mixed layer, the following relationship (Eq. 4) is valid for the steady state concentration $C_{\text {hal }}$, with $F_{\text {dia }}$ and $F_{\text {adv }}$ as the source terms from diapycnal fluxes and advection, while $S_{\text {as }}$ (Fig. 6) and $S_{\text {ch }}$ represent the loss terms sea-to-air flux and chemical sinks as described in the previous section:

$C_{\text {hal }}=F_{\text {dia }}+F_{\text {adv }}-S_{\text {as }}-S_{\text {ch }}$.

$S_{\text {as }}$ is the main sink term for $\mathrm{CHBr}_{3}, \mathrm{CH}_{2} \mathrm{Br}_{2}$ and $\mathrm{CH}_{3} \mathrm{I}$ during MSM18/3 (Table 6). On the short timescales considered here, diapycnal fluxes of $\mathrm{CH}_{3} \mathrm{I}$, which can reduce the mixed layer by around 5 pmol per hour (Table 5), compete with the loss due to chloride substitution $\left(S_{\mathrm{ch}}\right)$. For $\mathrm{CH}_{2} \mathrm{I}_{2}, S_{\mathrm{ch}}$ (photolysis) is about 10 times higher than $S_{\text {as }}$, and reduces the mixed layer budget by $24 \%$ after $1 \mathrm{~h}$. In total, diapycnal fluxes $\left(F_{\text {dia }}\right)$ into the mixed layer were not sufficient to account for the losses of all four compounds from the mixed layer (Table 6). The discrepancies with respect to the total mixed layer are $169\left(\mathrm{CH}_{2} \mathrm{Br}_{2}\right), 255\left(\mathrm{CH}_{3} \mathrm{I}\right), 269\left(\mathrm{CHBr}_{3}\right)$ to $8382\left(\mathrm{CH}_{2} \mathrm{I}_{2}\right) \mathrm{pmol} \mathrm{h}^{-1}$, which are small compared to the total amount of halocarbons in the mixed layer $\left(\mathrm{CHBr}_{3}\right.$ $\left.-0.17 \%, \mathrm{CH}_{2} \mathrm{Br}_{2}-0.19 \%, \mathrm{CH}_{3} \mathrm{I}-0.34 \%, \mathrm{CH}_{2} \mathrm{I}_{2}-13.11 \%\right)$. Possible reasons for the observed discrepancies are evaluated in the following. Advection of the missing halocarbons, $F_{\text {adv }}$, likely does not play a large role for $\mathrm{CH}_{2} \mathrm{Br}_{2}, \mathrm{CH}_{3} \mathrm{I}$ and $\mathrm{CH}_{2} \mathrm{I}_{2}$, since mean mixed layer concentrations of these compounds were rather homogeneous in the whole region. Thus, only for $\mathrm{CHBr}_{3}$, with more variable concentrations, advection may transport significant amounts from one location to another. In addition, halocarbon maxima were found within the mixed layer, which may either result from a mixed layer that is not well mixed or halocarbon production is faster than mixing in the mixed layer. According to the temperature and salinity profiles during the whole cruise (Fig. 3), the mixed layer was very well mixed. Consequently, production in the mixed layer is the most likely process balancing the missing halocarbons (Table 6) as diapycnal fluxes and advection play minor roles. The maxima that occasionally evolve in the mixed layer suggest that production of halocarbons is rapid, but may vary with depth. The mixed layer production term, here called $P_{\mathrm{ML}}$, has to be included in the budget calculation 
of Eq. (4):

$C_{\mathrm{hal}}=F_{\mathrm{dia}}+F_{\mathrm{adv}}-S_{\mathrm{as}}-S_{\mathrm{ch}}+P_{\mathrm{ML}}$.

The relative production of halocarbons in the mixed layer is likely largest for $\mathrm{CH}_{2} \mathrm{I}_{2}$, because its largest discrepancy arises from its rapid photolysis (up to $24 \%$ loss in $1 \mathrm{~h}$; Table 6). This is in agreement to earlier studies investigating macroalgal production, proposing larger release rates of $\mathrm{CH}_{2} \mathrm{I}_{2}$ than of $\mathrm{CHBr}_{3}, \mathrm{CH}_{2} \mathrm{Br}_{2}$ and $\mathrm{CH}_{3} \mathrm{I}$ (Klick and Abrahamsson, 1992; Carpenter et al., 2000).

\subsubsection{Production rates of halocarbons}

From the budget calculations, described in the previous section, potential production rates $P_{\mathrm{ML}}$ for the mixed layer are determined for each station. The mean production rates show large standard deviations (Table 7), including the variability and uncertainties in the estimated production rates. Production rates are $34 \pm 65\left(\mathrm{CHBr}_{3}\right), 10 \pm 12\left(\mathrm{CH}_{2} \mathrm{Br}_{2}\right), 21 \pm 24$ $\left(\mathrm{CH}_{3} \mathrm{I}\right)$, and $384 \pm 318 \mathrm{pmol} \mathrm{m}^{-3} \mathrm{~h}^{-1}\left(\mathrm{CH}_{2} \mathrm{I}_{2}\right)$. These are the first estimated production rates of $\mathrm{CHBr}_{3}$ and $\mathrm{CH}_{2} \mathrm{Br}_{2}$ for tropical phytoplankton species. For comparison to other studies, the production rates from this study are converted to rates per $\mu \mathrm{g} T \mathrm{Chl} a$ (reported in Tables 3 and 4), which results in mean ( \pm standard deviation) production rates of $2.5 \times 10^{-3} \pm 4.5 \times 10^{-3}\left(\mathrm{CHBr}_{3}\right), 8.4 \times 10^{-4} \pm 1.0 \times 10^{-3}$ $\left(\mathrm{CH}_{2} \mathrm{Br}_{2}\right), \quad 2.2 \times 10^{-3} \pm 3.0 \times 10^{-3} \quad\left(\mathrm{CH}_{3} \mathrm{I}\right) \quad$ and $3.3 \times 10^{-2} \pm 3.3 \times 10^{-2}$ pmol $[\mu \mathrm{g} T \mathrm{Chl} a]^{-1} \mathrm{~h}^{-1}\left(\mathrm{CH}_{2} \mathrm{I}_{2}\right)$.

\subsubsection{Comparison to previously reported rates - $\mathrm{CHBr}_{3}$ and $\mathrm{CH}_{2} \mathrm{Br}_{2}$}

Tokarczyk and Moore (1994) and Hughes et al. (2013) determined production rates from polar algae in laboratory studies ranging between $2 \times 10^{-3}$ and $2.1 \times 10^{-2} \mathrm{pmol}$ [ $\mu \mathrm{g}$ Chl $a]^{-1} \mathrm{~h}^{-1}$ on average for $\mathrm{CHBr}_{3}$, depending on the growth phase, which is in the range of our calculated rates. Production rates for $\mathrm{CH}_{2} \mathrm{Br}_{2}$ of on average 2.1$4.2 \times 10^{-3}$ pmol $[\mu \mathrm{g} \mathrm{Chl} a]^{-1} \mathrm{~h}^{-1}$ were much higher than the ones calculated in our study (Tokarczyk and Moore, 1994). Karlsson et al. (2008) published production rates of 2.6$9.3 \times 10^{-2}$ pmol $[\mu \mathrm{g} \mathrm{Chl} a]^{-1} \mathrm{~h}^{-1}$ for $\mathrm{CHBr}_{3}$ (depending on the time of day) and $5 \times 10^{-4}-3.6 \times 10^{-3} \mathrm{pmol}[\mu \mathrm{g} \mathrm{Chl} a]^{-1}$ $\mathrm{h}^{-1}$ for $\mathrm{CH}_{2} \mathrm{Br}_{2}$ from an in situ study in the Baltic Sea during a cyanobacterial bloom. Liu et al. (2011) calculated 417 $\left(\mathrm{CHBr}_{3}\right)$ and $258 \mathrm{pmol} \mathrm{m}^{-3} \mathrm{~h}^{-1}\left(\mathrm{CH}_{2} \mathrm{Br}_{2}\right)$ for the subtropical and temperate eastern US coast, which are tenfold higher than the production rates determined from our study (Table 7). The differences between these studies and ours may have several origins. Taking an average production rate for the total mixed layer during MSM18/3 does not take a potential variable production with depth into account. Second, the different production rates determined in the monocultural studies (Tokarczyk and Moore, 1994; Hughes et al., 2013) show large variations between different types of microalgae.
Third, the indirect estimates during MSM18/3 are afflicted by the uncertainties in the individual budget terms, which are also expressed in the large standard deviations.

\subsubsection{Comparison to previously reported rates $-\mathrm{CH}_{3} \mathrm{I}$ and $\mathrm{CH}_{2} \mathrm{I}_{2}$}

Production rates of $\mathrm{CH}_{3} \mathrm{I}$ determined from Prochlorococcus vary significantly from $5.8 \times 10^{-4}$ to $9.4 \times 10^{-2}$ pmol $[\mu \mathrm{g}$ Chl $a]^{-1} \mathrm{~h}^{-1}$ (Smythe-Wright et al., 2006; Brownell et al., 2010). Hughes et al. (2011) suggested this variability to be caused by different cell states, e.g. healthier cells producing less $\mathrm{CH}_{3} \mathrm{I}$. While Scarratt and Moore (1999) determined rates from $8.3 \times 10^{-3}-5.0 \times 10^{-2} \mathrm{pmol}[\mu \mathrm{g} \mathrm{Chl} a]^{-1} \mathrm{~h}^{-1}$ from a red microalgal species, Karlsson et al. (2008) reported a rate of $1.0 \times 10^{-2} \mathrm{pmol} \mathrm{CH}_{3} \mathrm{I}[\mu \mathrm{g} \mathrm{Chl} a]^{-1} \mathrm{~h}^{-1}$ from a cyanobacterial bloom in the Baltic Sea, which is at the higher end of the range mentioned here. Our estimates lie well within these cited ranges of phytoplankton production rates and are thus a reasonable assumption for the $\mathrm{CH}_{3} \mathrm{I}$ production strength of tropical algae (see Sect. 5.1.2).

In contrast to the other three halocarbons, very few studies have actually determined production rates of $\mathrm{CH}_{2} \mathrm{I}_{2}$ from phytoplankton. $\mathrm{CH}_{2} \mathrm{I}_{2}$ was shown to be produced in comparatively larger concentrations than other halocarbons, but generally from fewer species. Six polar and temperate $d i$ atom species were tested, of which only two produced $\mathrm{CH}_{2} \mathrm{I}_{2}$ (Moore et al., 1996). Martino et al. (2006) assumed a theoretical production rate of $17000 \mathrm{pmol} \mathrm{m}^{-3} \mathrm{~h}^{-1}$ in the tropical equatorial Atlantic. These were calculated from previously reported $\mathrm{CH}_{2} \mathrm{ClI}$ fluxes based on the assumption that $\mathrm{CH}_{2} \mathrm{ClI}$ is mainly formed during the photolysis of $\mathrm{CH}_{2} \mathrm{I}_{2}$ and that $\mathrm{CH}_{2} \mathrm{I}_{2}$ is only produced in the $T \mathrm{Chl} a$ maximum. This rate appears very large in comparison to our estimate and in comparison to the production rates of the other halocarbons. We showed evidence that $\mathrm{CH}_{2} \mathrm{I}_{2}$ is not only produced within the $T$ Chl $a$ maximum but in the whole mixed layer, thus, lower average production rates seem more plausible. $\mathrm{CH}_{2} \mathrm{I}_{2}$ together with $\mathrm{CH}_{2} \mathrm{ClI}$ have been suggested to be equally important carriers of organoiodine into the troposphere (SaizLopez et al., 2012), hence it is important to determine specific phytoplankton production rates of $\mathrm{CH}_{2} \mathrm{I}_{2}$ in future studies.

Our calculated production rates of $\mathrm{CHBr}_{3}, \mathrm{CH}_{2} \mathrm{Br}_{2}$ and $\mathrm{CH}_{3} \mathrm{I}$ lie well within the ranges of several laboratory and field studies of mostly temperate and polar algae, suggesting production from tropical algae to be similarly significant. $\mathrm{CH}_{2} \mathrm{I}_{2}$ was shown to be produced in larger rates than the other three compounds, but very rapid photolysis leads to lower sea surface concentrations of this compound. However, considering the large ranges in reported production rates of $\mathrm{CHBr}_{3}, \mathrm{CH}_{2} \mathrm{Br}_{2}, \mathrm{CH}_{3} \mathrm{I}$ and the lack of studies concentrating on $\mathrm{CH}_{2} \mathrm{I}_{2}$, more incubation experiments are severely needed to constrain in situ production rates of tropical algae. This information is crucial to evaluate the significance and contri- 
Table 6. Total mixed layer budget of each halocarbon, potential sinks and sources (box size $1 \times 1 \times z_{\mathrm{ML}} \mathrm{m}^{3}$ ). The upper four rows indicate cases where diapycnal fluxes act as sources, while the lower four rows summarize the budget for the cases where the diapycnal fluxes were sinks for the mixed layer budget. "Other sinks" is halogen substitution for $\mathrm{CH}_{3} \mathrm{I}$ and photolysis in case of $\mathrm{CH}_{2} \mathrm{I}_{2}$. The negative numbers indicate sinks for the budget.

\begin{tabular}{|c|c|c|c|c|c|c|c|c|}
\hline Unit & Compound & $\begin{array}{r}z_{\mathrm{ML}} \\
{[\mathrm{m}]}\end{array}$ & $\begin{array}{r}\text { Total ML } \\
\text { budget [pmol] }\end{array}$ & $\begin{array}{r}\text { Air-sea fluxes } \\
\left(S_{\text {as }}\right)\left[\mathrm{pmol} \mathrm{h}^{-1}\right]\end{array}$ & $\begin{array}{l}\text { Diapycnal fluxes } \\
\left(F_{\text {dia }}\right)\left[\mathrm{pmolh}^{-1}\right]\end{array}$ & $\begin{array}{r}\text { Other sinks } \\
\left(S_{\mathrm{ch}}\right)\left[\mathrm{pmolh}^{-1}\right]\end{array}$ & $\begin{array}{l}\text { Total after } \\
1 \mathrm{~h}[\mathrm{pmol}]\end{array}$ & $\begin{array}{r}\text { Difference } \\
\text { [pmol] }\end{array}$ \\
\hline \multirow{4}{*}{$\begin{array}{l}\text { Diapycnal fluxes } \\
\text { as source }\end{array}$} & $\mathrm{CHBr}_{3}$ & 24 & 157543 & -274 & 5 & & 157274 & -269 \\
\hline & $\mathrm{CH}_{2} \mathrm{Br}_{2}$ & 29 & 90058 & -172 & 3 & & 89889 & -169 \\
\hline & $\mathrm{CH}_{3} \mathrm{I}$ & 26 & 75263 & -257 & 2 & 0 & 75004 & -255 \\
\hline & $\mathrm{CH}_{2} \mathrm{I}_{2}$ & 28 & 63947 & -78 & 13 & -8317 & 55565 & -8382 \\
\hline \multirow{4}{*}{$\begin{array}{l}\text { Diapycnal fluxes } \\
\text { as sink }\end{array}$} & $\mathrm{CHBr}_{3}$ & 36 & 417098 & -1186 & -30 & & 415882 & -1216 \\
\hline & $\mathrm{CH}_{2} \mathrm{Br}_{2}$ & 27 & 99604 & -236 & -2 & & 99366 & -238 \\
\hline & $\mathrm{CH}_{3} \mathrm{I}$ & 29 & 137560 & -420 & -5 & 0 & 137135 & -425 \\
\hline & $\mathrm{CH}_{2} \mathrm{I}_{2}$ & 29 & 106587 & -35 & -2 & -4977 & 101573 & -5014 \\
\hline
\end{tabular}

Table 7. Theoretical mean production rate of the four halocarbons in the equatorial mixed layer with the standard deviation.

\begin{tabular}{lrrc}
\hline Compound & $\begin{array}{r}\text { Production rate } \\
{\left[\mathrm{pmol} \mathrm{m}^{-3} \mathrm{~h}^{-1}\right]}\end{array}$ & $\begin{array}{r}\text { Standard deviation } \\
{\left[\mathrm{pmol} \mathrm{m}^{-3} \mathrm{~h}^{-1}\right]}\end{array}$ & $\begin{array}{r}\text { Production rate per } T \mathrm{Chl} a \\
{\left[\mathrm{pmol}[\mu \mathrm{g} T \mathrm{Chl} a]^{-1} \mathrm{~h}^{-1}\right]}\end{array}$ \\
\hline $\mathrm{CHBr}_{3}$ & 34 & 65 & $2.5 \times 10^{-3}$ \\
$\mathrm{CH}_{2} \mathrm{Br}_{2}$ & 10 & 12 & $8.5 \times 10^{-4}$ \\
$\mathrm{CH}_{3} \mathrm{I}$ & 21 & 24 & $2.2 \times 10^{-3}$ \\
$\mathrm{CH}_{2} \mathrm{I}_{2}$ & 384 & 318 & $3.3 \times 10^{-2}$ \\
\hline
\end{tabular}

bution of the tropical ocean with respect to halogen transport into the troposphere, and finally into the stratosphere. Understanding the fate of halocarbons within the water column is an important task to estimate their distribution and emissions from the future ocean.

\section{Summary and conclusions}

Increased biological production during the Atlantic Cold Tongue (ACT) caused elevated $\mathrm{CHBr}_{3}$ and $\mathrm{CH}_{2} \mathrm{Br}_{2}$ concentrations of up to 44.7 and up to $9.2 \mathrm{pmol} \mathrm{L}^{-1}$ within the equatorial surface water with comparable concentrations to other tropical upwelling systems. Both compounds showed similar distributions and maxima in the region where the Equatorial Undercurrent (EUC) influences the surface water between 2 and $3^{\circ} \mathrm{S}$ with cooler water and elevated nutrients. Chrysophytes, the dominating phytoplankton group in the equatorial surface water, were likely involved in the bromocarbon production. In contrast to their similar surface water occurrence, $\mathrm{CHBr}_{3}$ and $\mathrm{CH}_{2} \mathrm{Br}_{2}$ showed different distributions in the water column. While $\mathrm{CHBr}_{3}$ was mostly elevated in shallower layers in close proximity to the $T \mathrm{Chl} a$ maximum, $\mathrm{CH}_{2} \mathrm{Br}_{2}$ frequently showed maxima in deeper water likely caused by an additional source.

In contrast to other tropical Atlantic regions, correlations of $\mathrm{CH}_{3} \mathrm{I}$ with $\mathrm{CHBr}_{3}$ and with biological parameters indicate biogenic formation of $\mathrm{CH}_{3} \mathrm{I}$ during the ACT. Moderate $\mathrm{CH}_{3} \mathrm{I}$ concentrations of up to $12.8 \mathrm{pmol} \mathrm{L}^{-1}$ were measured in the surface water. $\mathrm{CH}_{2} \mathrm{I}_{2}$ surface water and mixed layer concentrations were lowest due to its strong photolysis with maximum values of only $3.7 \mathrm{pmol} \mathrm{L}^{-1} \cdot \mathrm{CH}_{2} \mathrm{I}_{2}$ maxima below the mixed layer, suggest similar formation pathways to $\mathrm{CH}_{2} \mathrm{Br}_{2}$ possibly tied to heterotrophic activities below the layers of maximum production.

Sea-to-air fluxes were the most important sink from the mixed layer of $\mathrm{CHBr}_{3}, \mathrm{CH}_{2} \mathrm{Br}_{2}$ and $\mathrm{CH}_{3} \mathrm{I}$, while photolysis was the main sink for $\mathrm{CH}_{2} \mathrm{I}_{2}$. For the first time, halocarbon turbulent fluxes from and into the mixed layer were calculated using microstructure measurements and halocarbon concentration gradients in the water column. The significance of these diapycnal fluxes as a source for mixed layer halocarbons, suggested by halocarbon maxima below the mixed layer, was evaluated in comparison to sea-to-air fluxes and other sinks. All sinks of halocarbons from the mixed layer were much larger than the diapycnal supply into the mixed layer. Hence, halocarbon production in the entire mixed layer is the most important factor contributing to marine emissions of these compounds.

Production rates of halocarbons were estimated from 13 profiles for the tropical mixed layer. Calculated production rates varied between the stations and were $34 \pm 65$ for $\mathrm{CHBr}_{3}, 10 \pm 12$ for $\mathrm{CH}_{2} \mathrm{Br}_{2}, 21 \pm 24$ for $\mathrm{CH}_{3} \mathrm{I}$ and $384 \pm 318 \mathrm{pmol} \mathrm{m}^{-3} \mathrm{~h}^{-1}$ for $\mathrm{CH}_{2} \mathrm{I}_{2}$ with large variability between the different stations. These are generally in the range of rates reported from both monocultural and in situ incubation studies for $\mathrm{CHBr}_{3}, \mathrm{CH}_{2} \mathrm{Br}_{2}$ and $\mathrm{CH}_{3} \mathrm{I}$, while $\mathrm{CH}_{2} \mathrm{I}_{2}$ seems to be emitted in larger concentrations from phytoplankton.

Our results show the need to conduct more process-related studies in the field. The first consideration of diapycnal mixing revealed that maximum concentrations in the vicinity of the $T \mathrm{Chl} a$ maximum are insignificant for the mixed layer budget. Investigating the exact mechanisms of formation, degradation and transport of halocarbons in the water column remains an important task toward understanding current and future emissions of these compounds. Understanding the ac- 
tual processes that contribute to their concentrations and distribution within the water column is crucial to predict their emissions. We therefore suggest further mono-cultural incubation studies to determine species-dependent production and consumption rates. Temporally resolved in situ incubations in different depths within the water column in combination with diapycnal flux measurements will help to explain the profile shapes. Further halocarbon emission studies in the tropical ocean in different seasons are crucial to evaluate their importance for the stratospheric halogen loading in a global perspective.

Acknowledgements. We thank the chief scientist of the cruise MSM18/3 Arne Körtzinger, as well as the captain, the crew and the scientific crew of RV Maria S. Merian for all of their help. The authors acknowledge Sonja Wiegmann for pigment analysis, Bettina Taylor for CHEMTAX calculations, and Martina Lohmann for nutrient measurements. We thank Björn Fiedler for providing the fluorescence sensor data. We also appreciate the helpful input of Christa Marandino. Additionally, the authors acknowledge NASA for providing satellite MODIS-Aqua data of June and July 2011. This work was part of the German research project SOPRAN II and III (grant no. FKZ 03F0611A and 03F0662A) funded by the Bundesministerium für Bildung und Forschung (BMBF), and was also supported by the EU project SHIVA (grant no. FP7-ENV-2007-1-226224) and by the HGF Innovative Network Fund (PHYTOOPTICS project).

The article processing charges for this open-access publication were covered by a Research

Centre of the Helmholtz Association.

Edited by: X. Wang

\section{References}

Abrahamsson, K., Bertilsson, S., Chierici, M., Fransson, A., Froneman, P. W., Loren, A., and Pakhomov, E. A.: Variations of biochemical parameters along a transect in the southern ocean, with special emphasis on volatile halogenated organic compounds, Deep-Sea Res. Pt. II, 51, 2745-2756, doi:10.1016/j.dsr2.2004.09.004, 2004a.

Abrahamsson, K., Lorén, A., Wulff, A., and Wangberg, S. A.: Airsea exchange of halocarbons: The influence of diurnal and regional variations and distribution of pigments, Deep-Sea Res. Pt. II, 51, 2789-2805, doi:10.1016/j.dsr2.2004.09.005, 2004b.

Amachi, S.: Microbial contribution to global iodine cycling: Volatilization, accumulation, reduction, oxidation, and sorption of iodine, Microbes Environ., 23, 269-276, doi:10.1264/jsme2.ME08548, 2008.

Amachi, S., Kamagata, Y., Kanagawa, T., and Muramatsu, Y.: Bacteria mediate methylation of iodine in marine and terrestrial environments, Appl. Environ. Microbiol., 67, 2718-2722, doi:10.1128/aem.67.6.2718-2722.2001, 2001.

Amachi, S., Muramatsu, Y., Akiyama, Y., Miyazaki, K., Yoshiki, S., Hanada, S., Kamagata, Y., Ban-nai, T., Shinoyama, H., and
Fujii, T.: Isolation of iodide-oxidizing bacteria from iodide-rich natural gas brines and seawaters, Microb. Ecol., 49, 547-557, doi:10.1007/s00248-004-0056-0, 2005.

Aschmann, J., Sinnhuber, B.-M., Chipperfield, M. P., and Hossaini, R.: Impact of deep convection and dehydration on bromine loading in the upper troposphere and lower stratosphere, Atmos. Chem. Phys., 11, 2671-2687, doi:10.5194/acp-11-2671-2011, 2011.

Barlow, R. G., Cummings, D. G., and Gibb, S. W.: Improved resolution of mono- and divinyl chlorophylls $\mathrm{a}$ and $\mathrm{b}$ and zeaxanthin and lutein in phytoplankton extracts using reverse phase $\mathrm{c}-8 \mathrm{hplc}$, Mar. Ecol.-Prog. Ser., 161, 303-307, doi:10.3354/meps161303, 1997.

Bracher A., Taylor B. B., Taylor M., Dinter T., Röttgers R., and Steinmetz F.: Using empirical orthogonal functions derived from remote sensing reflectance for the prediction of concentrations of phytoplankton pigments, Ocean Sci., 11, 139-158, 2015, http://www.ocean-sci.net/11/139/2015/.

Brownell, D. K., Moore, R. M., and Cullen, J. J.: Production of methyl halides by prochlorococcus and synechococcus, Global Biogeochem. Cy., 24, GB2002, doi:10.1029/2009gb003671, 2010.

Carpenter, L. J. and Liss, P. S.: On temperate sources of bromoform and other reactive organic bromine gases, J. Geophys. Res.Atmos., 105, 20539-20547, doi:10.1029/2000JD900242.

Carpenter, L. J., Malin, G., Liss, P. S., and Kupper, F. C.: Novel biogenic iodine-containing trihalomethanes and other short-lived halocarbons in the coastal east atlantic, Global Biogeochem. Cy., 14, 1191-1204, doi:10.1029/2000GB001257, 2000.

Carpenter, L. J., Wevill, D. J., Palmer, C. J., and Michels, J.: Depth profiles of volatile iodine and bromine-containing halocarbons in coastal antarctic waters, Mar. Chem., 103, 227-236, doi:10.1016/j.marchem.2006.08.003, 2007.

Carpenter, L. J., Jones, C. E., Dunk, R. M., Hornsby, K. E., and Woeltjen, J.: Air-sea fluxes of biogenic bromine from the tropical and North Atlantic Ocean, Atmos. Chem. Phys., 9, 1805-1816, doi:10.5194/acp-9-1805-2009, 2009.

Claustre, H. and Marty, J. C.: Specific phytoplankton biomasses and their relation to primary production in the tropical northatlantic, Deep-Sea Res. Pt. I, 42, 1475-1493, doi:10.1016/09670637(95)00053-9, 1995.

Elliott, S. and Rowland, F. S.: Nucleophilic substitution rates and solubilities for methyl halides in seawater, Geophys. Res. Lett., 20, 1043-1046, doi:10.1029/93gl01081, 1993.

Elliott, S. and Rowland, F. S.: Methyl halide hydrolysis rates in natural waters, J. Atmos. Chem., 20, 229-236, doi:10.1007/bf00694495, 1995.

Fujiki, T., Matsumoto, K., Watanabe, S., Hosaka, T., and Saino, T.: Phytoplankton productivity in the western subarctic gyre of the north pacific in early summer 2006, J. Oceanogr., 67, 295-303, doi:10.1007/s10872-011-0028-1, 2011.

Fuse, H., Inoue, H., Murakami, K., Takimura, O., and Yamaoka, Y.: Production of free and organic iodine by roseovarius spp, FEMS Microbiol. Lett., 229, 189-194, doi:10.1016/s03781097(03)00839-5, 2003.

Geen, C. E.: Selected marine sources and sinks of bromoform and other low molecular weight organobromines, $\mathrm{PhD}$, Dalhousie University, Halifax, Halifax, Nova Scotia, 109 pp., 1992. 
Goodwin, K. D., Schaefer, J. K., and Oremland, R. S.: Bacterial oxidation of dibromomethane and methyl bromide in natural waters and enrichment cultures, Appl. Environ. Microbiol., 64, 46294636, 1998.

Grodsky, S. A., Carton, J. A., and McClain, C. R.: Variability of upwelling and chlorophyll in the equatorial atlantic, Geophys. Res. Lett., 35, L03610, doi:10.1029/2007g1032466, 2008.

Happell, J. D. and Wallace, D. W. R.: Methyl iodide in the greenland/norwegian seas and the tropical atlantic ocean: Evidence for photochemical production, Geophys. Res. Lett., 23, 2105-2108, doi:10.1029/96g101764, 1996.

Hense, I. and Quack, B.: Modelling the vertical distribution of bromoform in the upper water column of the tropical Atlantic Ocean, Biogeosciences, 6, 535-544, doi:10.5194/bg-6-535-2009, 2009.

Hepach, H., Quack, B., Ziska, F., Fuhlbrügge, S., Atlas, E. L., Krüger, K., Peeken, I., and Wallace, D. W. R.: Drivers of diel and regional variations of halocarbon emissions from the tropical North East Atlantic, Atmos. Chem. Phys., 14, 1255-1275, doi:10.5194/acp-14-1255-2014, 2014.

Hopkins, F. E., Kimmance, S. A., Stephens, J. A., Bellerby, R. G. J., Brussaard, C. P. D., Czerny, J., Schulz, K. G., and Archer, S. D.: Response of halocarbons to ocean acidification in the Arctic, Biogeosciences, 10, 2331-2345, doi:10.5194/bg-10-2331-2013, 2013.

Hossaini, R., Chipperfield, M. P., Monge-Sanz, B. M., Richards, N. A. D., Atlas, E., and Blake, D. R.: Bromoform and dibromomethane in the tropics: a 3-D model study of chemistry and transport, Atmos. Chem. Phys., 10, 719-735, doi:10.5194/acp10-719-2010, 2010.

Hossaini, R., Chipperfield, M. P., Feng, W., Breider, T. J., Atlas, E., Montzka, S. A., Miller, B. R., Moore, F., and Elkins, J.: The contribution of natural and anthropogenic very short-lived species to stratospheric bromine, Atmos. Chem. Phys., 12, 371380, doi::10.5194/acp-12-371-2012, 2012.

Hughes, C., Chuck, A. L., Rossetti, H., Mann, P. J., Turner, S. M., Clarke, A., Chance, R., and Liss, P. S.: Seasonal cycle of seawater bromoform and dibromomethane concentrations in a coastal bay on the western antarctic peninsula, Global Biogeochem. Cy., 23, Gb2024, doi:10.1029/2008gb003268, 2009.

Hughes, C., Franklin, D. J., and Malin, G.: Iodomethane production by two important marine cyanobacteria: Prochlorococcus marinus (ccmp 2389) and synechococcus sp (ccmp 2370), Mar. Chem., 125, 19-25, doi:10.1016/j.marchem.2011.01.007, 2011.

Hughes, C., Johnson, M., Utting, R., Turner, S., Malin, G., Clarke, A., and Liss, P. S.: Microbial control of bromocarbon concentrations in coastal waters of the western antarctic peninsula, Mar. Chem., 151, 35-46, doi:10.1016/j.marchem.2013.01.007, 2013.

Hummels, R., Dengler, M., and Bourles, B.: Seasonal and regional variability of upper ocean diapycnal heat flux in the atlantic cold tongue, Prog. Oceanogr., 111, 52-74, doi:10.1016/j.pocean.2012.11.001, 2013.

Itoh, N., Tsujita, M., Ando, T., Hisatomi, G., and Higashi, T.: Formation and emission of monohalomethanes from marine algae, Phytochemistry, 45, 67-73, doi:10.1016/s0031-9422(96)007868, 1997.

Jin, Z. H., Charlock, T. P., Rutledge, K., Stamnes, K., and Wang, Y. J.: Analytical solution of radiative transfer in the coupled atmosphere-ocean system with a rough surface, Appl. Opt., 45, 7443-7455, doi:10.1364/ao.45.007443, 2006.
Johnson, Z. I., Zinser, E. R., Coe, A., McNulty, N. P., Woodward, E. M. S., and Chisholm, S. W.: Niche partitioning among prochlorococcus ecotypes along ocean-scale environmental gradients, Science, 311, 1737-1740, doi:10.1126/science.1118052, 2006.

Jones, C. E. and Carpenter, L. J.: Solar photolysis of $\mathrm{ch}_{2} \mathrm{i}_{2}, \mathrm{ch}_{2} \mathrm{ici}$, and $\mathrm{ch}_{2} \mathrm{ibr}$ in water, saltwater, and seawater, Environ. Sci. Technol., 39, 6130-6137, doi:10.1021/es050563g, 2005.

Jones, C. E. and Carpenter, L. J.: Chemical destruction of ch3ic2h5i, c2h5i, 1-c3h7i, and 2-c3h7i in saltwater, Geophys. Res. Lett., 34, L13804, doi:10.1029/2007g1029775, 2007.

Jones, C. E., Hornsby, K. E., Sommariva, R., Dunk, R. M., Von Glasow, R., McFiggans, G., and Carpenter, L. J.: Quantifying the contribution of marine organic gases to atmospheric iodine, Geophys. Res. Lett., 37, L18804, doi:10.1029/2010g1043990, 2010.

Jouanno, J., Marin, F., du Penhoat, Y., Sheinbaum, J., and Molines, J. M.: Seasonal heat balance in the upper $100 \mathrm{~m}$ of the equatorial atlantic ocean, J. Geophys. Res.-Oceans, 116, C09003, doi:10.1029/2010jc006912, 2011.

Kara, A. B., Rochford, P. A., and Hurlburt, H. E.: An optimal definition for ocean mixed layer depth, J. Geophys. Res.-Oceans, 105, 16803-16821, doi:10.1029/2000jc900072, 2000.

Karlsson, A., Auer, N., Schulz-Bull, D., and Abrahamsson, K.: Cyanobacterial blooms in the baltic - a source of halocarbons, Mar. Chem., 110, 129-139, doi:10.1016/j.marchem.2008.04.010, 2008.

Kirkham, A. R., Jardillier, L. E., Tiganescu, A., Pearman, J., Zubkov, M. V., and Scanlan, D. J.: Basin-scale distribution patterns of photosynthetic picoeukaryotes along an atlantic meridional transect, Environ. Microbiol., 13, 975-990, doi:10.1111/j.1462-2920.2010.02403.x, 2011.

Klick, S. and Abrahamsson, K.: Biogenic volatile iodated hydrocarbons in the ocean, J. Geophys. Res.-Oceans, 97, 12683-12687, doi:10.1029/92jc00948, 1992.

Kolber, Z. and Falkowski, P. G.: Use of active fluorescence to estimate phytoplankton photosynthesis in-situ, Limnol. Oceanogr., 38, 1646-1665, doi:10.4319/lo.1993.38.8.1646, 1993.

Kurihara, M. K., Kimura, M., Iwamoto, Y., Narita, Y., Ooki, A., Eum, Y. J., Tsuda, A., Suzuki, K., Tani, Y., Yokouchi, Y., Uematsu, M., and Hashimoto, S.: Distributions of short-lived iodocarbons and biogenic trace gases in the open ocean and atmosphere in the western north pacific, Mar. Chem., 118, 156170, doi:10.1016/j.marchem.2009.12.001, 2010.

Laturnus, F.: Marine macroalgae in polar regions as natural sources for volatile organohalogens, Environ. Sci. Pollut. Res., 8, 103108, doi:10.1007/bf02987302, 2001.

Lin, C. Y. and Manley, S. L.: Bromoform production from seawater treated with bromoperoxidase, Limnol. Oceanogr., 57, 1857 1866, doi:10.4319/10.2012.57.06.1857, 2012.

Liu, Y. N., Yvon-Lewis, S. A., Hu, L., Salisbury, J. E., and O'Hern, J. E.: $\operatorname{Chbr}(3), \operatorname{ch}(2) \operatorname{br}(2)$, and chclbr(2) in u.S. Coastal waters during the gulf of mexico and east coast carbon cruise, J. Geophys. Res.-Oceans, 116, C10004, doi:10.1029/2010jc006729, 2011.

Liu, Y. N., Yvon-Lewis, S. A., Thornton, D. C. O., Campbell, L., and Bianchi, T. S.: Spatial distribution of brominated very shortlived substances in the eastern pacific, J. Geophys. Res.-Oceans, 118, 2318-2328, doi:10.1002/jgrc.20183, 2013a.

Liu, Y. N., Yvon-Lewis, S. A., Thornton, D. C. O., Butler, J. H., Bianchi, T. S., Cambell, L., Hu, L., and Smith, R. W.: 
Spatial and temporal distributions of bromoform and dibromomethane in the atlantic ocean and their relationship with photosynthetic biomass, J. Geophys. Res.-Oceans, 118, 3950-3965, doi:10.1002/jgrc.20299, 2013b.

Liu, Y. N., Thornton, D. C. O., Bianchi, T. S., Arnold, W. A., Shields, M. R., Chen, J., and Yvon-Lewis, S. A.: Dissolved organic matter composition drives the marine production of brominated very short-lived substances, Environ. Sci. Technol., 49, 3366-3374, doi:10.1021/es505464k, 2015.

Mabey, W. and Mill, T.: Critical review of hydrolysis of organic compounds in water under environmental conditions, J. Phys. Chem. Ref. Data, 7, 383-415, doi:10.1063/1.555572, 1978.

Mackey, M. D., Mackey, D. J., Higgins, H. W., and Wright, S. W.: Chemtax - a program for estimating class abundances from chemical markers: Application to hplc measurements of phytoplankton, Mar. Ecol.-Prog. Ser., 144, 265-283, doi:10.3354/meps144265, 1996.

Manley, S. L. and Dastoor, M. N.: Methyl-iodide (ch3i) production by kelp and associated microbes, Mar. Biol., 98, 477-482, doi:10.1007/BF00391538, 1988.

Manley, S. L. and de la Cuesta, J. L.: Methyl iodide production from marine phytoplankton cultures, Limnol. Oceanogr., 42, 142-147, doi:10.4319/lo.1997.42.1.0142, 1997.

Martino, M., Liss, P. S., and Plane, J. M. C.: The photolysis of dihalomethanes in surface seawater, Environ. Sci. Technol., 39, 7097-=7101, doi:10.1021/es048718s, 2005.

Martino, M., Liss, P. S., and Plane, J. M. C.: Wavelengthdependence of the photolysis of diiodomethane in seawater, Geophys. Res. Lett., 33, L06606, doi:10.1029/2005g1025424, 2006.

Martino, M., Mills, G. P., Woeltjen, J., and Liss, P. S.: A new source of volatile organoiodine compounds in surface seawater, Geophys. Res. Lett., 36, L01609, doi:10.1029/2008g1036334, 2009.

Molinari, R. L.: Observations of eastwad currents in the tropical south-atlantic ocean - 1978 - 1980, J. Geophys. Res.-Oceans, 87, 9707-9714, doi:10.1029/JC087iC12p09707, 1982.

Moore, R. M. and Groszko, W.: Methyl iodide distribution in the ocean and fluxes to the atmosphere, J. Geophys. Res.-Oceans, 104, 11163-11171, doi:10.1029/1998jc900073, 1999.

Moore, R. M. and Tokarczyk, R.: Volatile biogenic halocarbons in the northwest atlantic, Global Biogeochem. Cy., 7, 195-210, doi:10.1029/92GB02653, 1993.

Moore, R. M. and Zafiriou, O. C.: Photochemical production of methyl-iodide in seawater, J. Geophys. Res.-Atmos., 99, 1641516420, doi:10.1029/94jd00786, 1994.

Moore, R. M., Geen, C. E., and Tait, V. K.: Determination of henry law constants for a suite of naturally-occurring halogenated methanes in seawater, Chemosphere, 30, 1183-1191, doi:10.1016/0045-6535(95)00009-w, 1995a.

Moore, R. M., Tokarczyk, R., Tait, V. K., Poulin, M., and Geen, C. E.: Marine phytoplankton as a natural source of volatile organohalogens, in: Naturally-produced organohalogens, edited by: Grimvall, A. and deLeer, E. W. B., Kluwer Academic Publishers, Dordrecht, 283-294, 1995b.

Moore, R. M., Webb, M., Tokarczyk, R., and Wever, R.: Bromoperoxidase and iodoperoxidase enzymes and production of halogenated methanes in marine diatom cultures, J. Geophys. Res.Oceans, 101, 20899-20908, doi:10.1029/96jc01248, 1996.

Nightingale, P. D., Malin, G., and Liss, P. S.: Production of chloroform and other low-molecular-weight halocarbons by some species of macroalgae, Limnol. Oceanogr., 40, 680-689, doi:10.4319/lo.1995.40.4.0680, 1995.

Nightingale, P. D., Malin, G., Law, C. S., Watson, A. J., Liss, P. S., Liddicoat, M. I., Boutin, J., and Upstill-Goddard, R. C.: In situ evaluation of air-sea gas exchange parameterizations using novel conservative and volatile tracers, Global Biogeochem. Cy., 14 373-387, doi:10.1029/1999gb900091, 2000.

Orlikowska, A. and Schulz-Bull, D. E.: Seasonal variations of volatile organic compounds in the coastal baltic sea, Environ. Chem., 6, 495-507, doi:10.1071/en09107, 2009.

Osborn, T. R.: Estimates of the local rate of vertical diffusion from dissipation measurements, J. Phys. Oceanogr., 10, 83-89, doi:10.1175/1520-0485(1980)010<0083:eotlro> 2.0.co;2, 1980.

Penkett, S. A., Jones, B. M. R., Rycroft, M. J., and Simmons, D. A.: An interhemispheric comparison of the concentrations of bromine compounds in the atmosphere, Nature, 318, 550-553, doi:10.1038/318550a0, 1985.

Philander, S. G. H. and Pacanowski, R. C.: A model of the seasonal cycle in the tropical atlantic ocean, J. Geophys. Res.-Oceans, 91, 14192-14206, doi:10.1029/JC091iC12p14192, 1986.

Quack, B. and Wallace, D. W. R.: Air-sea flux of bromoform: Controls, rates, and implications, Global Biogeochem. Cy., 17, 1023, doi:10.1029/2002gb001890, 2003.

Quack, B., Atlas, E., Petrick, G., Stroud, V., Schauffler, S., and Wallace, D. W. R.: Oceanic bromoform sources for the tropical atmosphere, Geophys. Res. Lett., 31, L23s05, doi:10.1029/2004gl020597, 2004.

Quack, B., Atlas, E., Petrick, G., and Wallace, D. W. R.: Bromoform and dibromomethane above the mauritanian upwelling: Atmospheric distributions and oceanic emissions, J. Geophys. Res.Atmos., 112, D09312, doi:10.1029/2006jd007614, 2007a.

Quack, B., Peeken, I., Petrick, G., and Nachtigall, K.: Oceanic distribution and sources of bromoform and dibromomethane in the mauritanian upwelling, J. Geophys. Res.-Oceans, 112, C10006, doi:10.1029/2006jc003803, 2007b.

Raimund, S., Quack, B., Bozec, Y., Vernet, M., Rossi, V., Garçon, V., Morel, Y., and Morin, P.: Sources of short-lived bromocarbons in the Iberian upwelling system, Biogeosciences, 8, 15511564, doi:10.5194/bg-8-1551-2011, 2011.

Richter, U.: Factors influencing methyl iodide production in the ocean and its flux to the atmosphere, $\mathrm{PhD}$, MathematischNaturwissenschaftliche Fakultät der Christian-AlbrechtsUniversität zu Kiel, Christian-Albrechts-Universität zu Kiel, Kiel, 117 pp., 2004.

Richter, U. and Wallace, D. W. R.: Production of methyl iodide in the tropical atlantic ocean, Geophys. Res. Lett., 31, L23s03, doi:10.1029/2004g1020779, 2004.

Round, F. E.: The chrysophyta - a reassessment, in: Chrysophytes: Aspects and problems, edited by: Kristiansen, J. and Andersen, R. A., Cambridge University Press, Cambridge, 3-22, 1986.

Saiz-Lopez, A., Plane, J. M. C., Baker, A. R., Carpenter, L. J., von Glasow, R., Martin, J. C. G., McFiggans, G., and Saunders, R. W.: Atmospheric chemistry of iodine, Chem. Rev., 112, 17731804, doi:10.1021/cr200029u, 2012.

Scarratt, M. G. and Moore, R. M.: Production of methyl bromide and methyl chloride in laboratory cultures of marine phytoplankton ii, Mar. Chem., 59, 311-320, doi:10.1016/s03044203(97)00092-3, 1998. 
Scarratt, M. G. and Moore, R. M.: Production of chlorinated hydrocarbons and methyl iodide by the red microalga porphyridium purpureum, Limnol. Oceanogr., 44, 703-707, doi:10.4319/lo.1999.44.3.0703, 1999.

Schafstall, J., Dengler, M., Brandt, P., and Bange, H: Tidalinduced mixing and diapycnal nutrient fluxes in the mauritanian upwelling region, J. Geophys. Res.-Oceans, 115, C10014, doi:10.1029/2009jc005940, 2010.

Schall, C., Heumann, K. G., and Kirst, G. O.: Biogenic volatile organoiodine and organobromine hydrocarbons in the atlantic ocean from $42^{\circ} \mathrm{N}$ to $72^{\circ} \mathrm{S}$, Fresenius J. Anal. Chem., 359, 298305, doi:10.1007/s002160050577, 1997.

Schauffler, S. M., Atlas, E. L., Flocke, F., Lueb, R. A., Stroud, V., and Travnicek, W.: Measurements of bromine containing organic compounds at the tropical tropopause, Geophys. Res. Lett., 25, 317-320, doi:10.1029/98GL00040, 1998.

Schlundt, M., Brandt, P., Dengler, M., Hummels, R., Fischer, T., Bumke, K., Krahmann, G., and Karstensen, J.: Mixed layer heat and salinity budgets during the onset of the 2011 Atlantic cold tongue, J. Geophys. Res.-Oceans, 119, 7882-7910, doi:10.1002/2014jc010021, 2014.

Smythe-Wright, D., Boswell, S. M., Breithaupt, P., Davidson, R. D., Dimmer, C. H., and Diaz, L. B. E.: Methyl iodide production in the ocean: Implications for climate change, Global Biogeochem. Cy., 20, Gb3003, doi:10.1029/2005gb002642, 2006.

Smythe-Wright, D., Peckett, C., Boswell, S., and Harrison, R.: Controls on the production of organohalogens by phytoplankton: Effect of nitrate concentration and grazing, J. Geophys. Res.Biogeosci., 115, G03020, doi:10.1029/2009jg001036, 2010.

Solomon, S., Garcia, R. R., and Ravishankara, A. R.: On the role of iodine in ozone depletion, J. Geophys. Res.-Atmos., 99, 2049120499, doi:10.1029/94jd02028, 1994.

Stramma, L. and Schott, F.: The mean flow field of the tropical atlantic ocean, Deep-Sea Res. Pt. II, 46, 279-303, doi:10.1016/s0967-0645(98)00109-x, 1999.

Taylor, B. B., Torrecilla, E., Bernhardt, A., Taylor, M. H., Peeken, I., Röttgers, R., Piera, J., and Bracher, A.: Bio-optical provinces in the eastern Atlantic Ocean and their biogeographical relevance, Biogeosciences, 8, 3609-3629, doi:10.5194/bg-8-36092011, 2011.

Tegtmeier, S., Krüger, K., Quack, B., Atlas, E. L., Pisso, I., Stohl, A., and Yang, X.: Emission and transport of bromocarbons: from the West Pacific ocean into the stratosphere, Atmos. Chem. Phys., 12, 10633-10648, doi:10.5194/acp-12-10633-2012, 2012.

Tegtmeier, S., Krüger, K., Quack, B., Atlas, E., Blake, D. R., Boenisch, H., Engel, A., Hepach, H., Hossaini, R., Navarro, M. A., Raimund, S., Sala, S., Shi, Q., and Ziska, F.: The contribution of oceanic methyl iodide to stratospheric iodine, Atmos. Chem. Phys., 13, 11869-11886, doi:10.5194/acp-1311869-2013, 2013.
Tokarczyk, R. and Moore, R. M.: Production of volatile organohalogens by phytoplankton cultures, Geophys. Res. Lett., 21, 285288, doi:10.1029/94GL00009, 1994.

Tomczak, M. and Godfrey, J. S.: Regional oceanography: An introduction, in, 2 ed., Daya Publishing House, Delhi, 15, 253-270, 2005.

Tsuchiya, M., Talley, L. D., and McCartney, M. S.: An eastern atlantic section from iceland southward across the equator, DeepSea Res., 39, 1885-1917, doi:10.1016/0198-0149(92)90004-d, 1992.

Veldhuis, M. J. W. and Kraay, G. W.: Phytoplankton in the subtropical atlantic ocean: Towards a better assessment of biomass and composition, Deep-Sea Res. Pt. I, 51, 507-530, doi:10.1016/j.dsr.2003.12.002, 2004.

Wang, L., Moore, R. M., and Cullen, J. J.: Methyl iodide in the nw atlantic: Spatial and seasonal variation, J. Geophys. Res.-Oceans, 114, C07007, doi:10.1029/2007jc004626, 2009.

Weingartner, T. J. and Weisberg, R. H.: On the annual cycle of equatorial upwelling in the central aatlantic-ocean, J. Phys. Oceanogr., 21, 68-82, doi:10.1175/1520-0485(1991)021< 0068:otacoe> 2.0.co;2, 1991.

Yamamoto, H., Yokouchi, Y., Otsuki, A., and Itoh, H.: Depth profiles of volatile halogenated hydrocarbons in seawater in the bay of bengal, Chemosphere, 45, 371-377, doi:10.1016/s00456535(00)00541-5, 2001.

Zika, R. G., Gidel, L. T., and Davis, D. D.: A comparison of photolysis and substitution decomposition rates of methyl-iodide in the ocean, Geophys. Res. Lett., 11, 353-356, doi:10.1029/GL011i004p00353, 1984.

Ziska, F., Quack, B., Abrahamsson, K., Archer, S. D., Atlas, E., Bell, T., Butler, J. H., Carpenter, L. J., J ones, C. E., Harris, N. R. P., Hepach, H., Heumann, K. G., Hughes, C., Kuss, J., Krüger, K., Liss, P., Moore, R. M., Orlikowska, A., Raimund, S., Reeves, C. E., Reifenhäuser, W., Robinson, A. D., Schall, C., Tanhua, T., Tegtmeier, S., Turner, S., Wang, L., Wallace, D., Williams, J., Yamamoto, H., Yvon-Lewis, S., and Yokouchi, Y.: Global sea-toair flux climatology for bromoform, dibromomethane and methyl iodide, Atmos. Chem. Phys., 13, 8915-8934, doi:10.5194/acp13-8915-2013, 2013. 